Article

\title{
Strategy Context of Decision Making for Improved Energy Efficiency in Industrial Energy Systems
}

\author{
Alexander Melnik and Kirill Ermolaev*(D) \\ Department of Innovation and Investment, Kazan (Volga region) Federal University, Kazan 420008, Russia; \\ Alexander.Melnik@kpfu.ru \\ * Correspondence: KiAErmolaev@kpfu.ru
}

Received: 23 January 2020; Accepted: 19 March 2020; Published: 25 March 2020

\begin{abstract}
Energy efficiency improvement in industrial companies is an essential prerequisite for the enhancement of their competitive positions in the national and global markets. Yet, the approaches currently employed in respect of the energy management do not fully utilize the innovative potential of energy technologies to achieve strategic goals. One way to further develop energy management is theoretical justification of the use of new approaches based on the suggested concept of the energy saving and energy efficiency processes' positioning in the system of a company's management priorities. In this article, we consider the applied use of the developed conceptual approach from the perspective of the energy saving and energy efficiency program development at the company. The main purpose of this paper is to justify the relations between energy management and strategic decision making in industrial companies. The results of the research conducted, firstly, make a certain contribution into the research of strategic multiple benefits of energy efficiency in a company; secondly, they expand understanding of the impact of energy saving and energy efficiency improvement on the achievement of operational, tactical and strategic results of the company's activities; thirdly, they provide methodological decision support for the development of energy saving and energy efficiency programs taking into account the management and organizational barriers.
\end{abstract}

Keywords: energy efficiency; energy management; innovative development; energy policy; industry; decision making; indirect benefits of energy efficiency

\section{Introduction}

It is no coincidence that many countries of the world have recognized the efforts put into addressing the large-scale problem of enhancing the energy security of national economies. This has a unifying nature from the point of view of the national interests, as the most important priority of innovative development. This priority status provides a powerful impetus to the innovative modernization of national economies and helps increase their competitiveness as the new wave of innovation comes into being. At the same time, energy efficiency is only one of the possible ways of the energy security enhancement of the national economy along with increasing the use of renewable energy generation resources, conclusion of long-term contracts on energy resources supply, introduction of internal regulations and standards on energy consumption, participation in international programs on scientific research in the energy field, etc.

Moreover, in developed and developing countries, views on energy efficiency as a public policy area differ as well. In developed countries, energy efficiency is considered, first of all, from the standpoint of the energy impact on the environment and climate change. This approach implies minimizing a negative environmental impact, achieved by the rational use of energy resources [1-3]. This focus area is characterized by particular attention to the effects of human society on nature and desire to maintain a favorable environment for new generations [4-7]. Unlike developed countries, 
for developing ones, the context of energy efficiency has a slightly different priority [8-10]. The policy of energy efficiency improvement is considered, first of all, as the area of modernization of various industries and individual companies in order to reduce production cost and increase their competitiveness at the world markets. The importance of implementing this area of national economy advancement in developing countries is particularly high where there is a big share of energy consumption in production costs. Therefore, developing countries' policy in the field of energy efficiency improvement is focused, first of all, on technical reequipment and industrial production modernization in various branches. Studies of various scientists confirm that energy efficiency drivers for developed and developing countries may differ [11,12].

According to the International Energy Agency (IEA) industrial companies consume about $38 \%$ of the total final energy consumption in the world. At the same time, in industrial companies, introduction of solutions, developed in the energy efficiency field to date, will improve its value twice as much by 2040 . However, the conceptual and methodological approaches that have been developed to date in order to manage energy saving and energy efficiency improvement in industrial companies are primarily focused on solving current production and operation problems. These approaches tend to focus on such problems as a result of operational efficiency improvement of equipment and technological processes applied [13-16]. However, the issues linked with energy saving and energy efficiency improvement impact exerted on achieving strategic goals of the company's development, including competitiveness improvement at the national and world markets, remain insufficiently studied $[17,18]$. The current situation is one of the barriers to energy efficiency improvement, hampering company's development in the context of the ongoing transition of the global economy to an innovative development path. That is why the current research objective is to form a conceptual framework for energy saving management and energy efficiency improvement. It is implied that this framework should be focused on using the innovative potential of developments in the field of energy technologies in order to achieve the strategic goals of company's development.

\section{Literature Review}

Despite the diversity of existing approaches to addressing the energy efficiency issue, researchers from different countries agree that it is important for the development of economy [19-21]. To this end, a special focus is put on the need to use innovations in the implementation of energy efficiency measures [22-24], as well as on the study of the causes and barriers that hinder energy efficiency when introducing innovative technologies [25]. At the same time, the need for development, implementation and dissemination of "energy-efficient innovations" is recognized by the experts from different countries as the most important task at different levels of economic management [26-28]. On the other hand, the creation of appropriate conditions is perceived as the most important area of public policy $[12,29,30]$. The studies of researchers from different countries widely discuss the causes and barriers in the way of implementation of this public policy, external and internal factors, as well as conditions of its implementation [31-33]. The research is underlain by a fair assumption that innovation is an essential factor and a prerequisite for improving the energy efficiency of national economies [34-36]. Consequently, the tasks to be addressed in this context are focused on the search for ways to activate the processes of increasing energy efficiency through the use of new innovative approaches [37-40].

Thus, for example, as a result of the study of the conditions necessary for the successful implementation of energy-efficient solutions in a number of European companies, a positive correlation between the production of innovative products and the introduction of energy-efficient technologies was identified [41,42]. Some Italian companies were used as an example to substantiate the assumption that the diversification of innovation activities is a crucial factor in the improvement of energy efficiency [43,44]. Similar results have been obtained by Chinese [45,46] and Korean experts [47]. They, upon studying the activities of national industrial companies, have confirmed the significant impact of innovation activity results on energy efficiency in production. An interesting study was 
carried out in terms of considering energy efficiency as the most important goal of innovative activities of Spanish companies. Consequently, they identified a framework of factors influencing successful achievement of energy efficiency, including the size of the company, solution of environmental problems, implementation of organizational innovations, etc. [48,49]. The outcomes obtained by researchers from different countries suggest two characteristic features of competitive companies. They are, firstly, more active in implementing innovations in order to improve the energy efficiency of their operations. Secondly, they consider the improvement of energy efficiency of their operations as the most important strategic priority for their development. A number of studies have highlighted that the production of innovative products and energy efficiency improvements is a complex and highly controversial process. Consequently, over-emphasis on one side of this process can have an indirect adverse impact on the other side $[50,51]$.

All this leads to the conclusion that there is a certain mutual influence of energy saving and energy efficiency improvement processes and innovative development of industrial companies $[52,53]$. On the one hand, the improvement of efficiency of energy resources utilization on an innovative basis allows the company to address a whole set of tasks related to the reduction of the production costs and increase of competitiveness of the production output. On the other hand, energy saving and energy efficiency can be considered as a top priority for innovative development and innovative modernization of national economies.

Today, a large number of methodological approaches have emerged that assume modeling the operations of the companies' energy facilities with different levels of detailing. In the professional literature on management, the model used for this purpose is usually called a "black box" [54,55]. It does not discuss the organizational structure of the energy facilities and processes taking place therein. Rather, it only determines the flow of incoming and outcoming signals such as, for example, energy consumption indicators, technical and economic performance indicators of the division's activities, etc. The correlation analysis method based on the processing of historical statistical information, which has become widespread in the practice of economic research, is most frequently used for the purposes of studying such models [56,57]. The use of the so-called energy utilities functioning model considered as a derivative of the production system functioning model [58-61] has become widespread in addressing the problem under study.

The researchers studying the problem in question put a great emphasis on the processes of modeling with the application of the industrial energy systems analysis method MIND (Method for analysis of INDustrial energy systems) [62-64]. Its application assumes the development of mathematical models of the mixed integer linear programming in order to identify economically viable administrative measures within the boundaries of the industrial enterprise of any size. This is aimed at the subsequent optimization of the company's production processes. Thus, for example, in the research by Thollander P. [65], it is proposed to use the method of optimization of the industrial enterprises' energy utilities. The research by Karlsson M. [66] offers an approach to optimization on the basis of using the mixed integer linear programming method to assess the economic efficiency of the interaction between industrial enterprises within the industrial cluster. The research by Malatji E.M. [67], Diakaki C. [68] and Soetanto R. [69] discusses the models for optimizing investment in energy efficiency improvements in buildings. The models proposed allow solving the problem of multi-criteria optimization. According to the author, the models and algorithms developed can be used by industrial companies in solving practical development problems.

The approaches discussed above incorporate effort to develop appropriate models from the level of management of individual production processes towards the enterprise management level. Thus, as a rule, such economic indicators as the reduction of production energy costs and production energy intensity, etc., are taken as the main criteria for decision-making in the optimization of production processes. However, this approach is not always justified when addressing management tasks in the field of energy saving and energy efficiency. 
It is, first of all, explained by the assumption that when making managerial decisions, not only the characteristics of the production system should be taken into account but also the external conditions of the company's functioning [70]. This process should pursue not only the possible reduction of energy costs or other similar economic indicators but also should account for the indicators of investment efficiency, strategic viability, technical reliability of production, environmental consequences, etc. In part, such tasks are solved under energy-efficient production planning (EEPP) approaches, which set the goals of production planning while minimizing energy consumption, reducing greenhouse gas emissions, observing maximum power consumption, etc. It should be emphasized that such approaches have appeared only recently. For this reason, firstly, today only a few integrated decision support models for EEPP have been proposed, and secondly, all these models are applicable to only short-term and medium-term production planning, leaving strategic perspectives outside the scope of research [71]. Therefore, when using such approaches, one can clearly see the impossibility of coordinating operational, tactical and strategic decisions in a unified system of the company's energy saving and energy efficiency management. At the same time, the problems of the impact of energy saving and energy efficiency on the achievement of the company's strategic development goals remain beyond the scope of the research.

That is why this study proceeds from a broader understanding of the nature of the possible impact of innovative processes in the field of energy conservation and energy efficiency on the company's strategic development. This understanding in no way limits our scope to the traditional operational tasks. Under this approach, we rest upon development of the of Cooremans' C. idea about the need to take into account a strategic nature of energy efficiency investments through the use of the conceptual model of "competitive advantage". This model includes three interrelated components: "value", "cost" and "risks" [72]. From the perspective of the Cooremans' C. conceptual model, we pay special attention and disclose more thoroughly the features of investment activities in the field of energy saving and energy efficiency improvement, which are related to the cost component. In addition, in our approach, we consider one more component, "innovation". In terms of the Cooremans' C. conceptual model, it has a potential of "value" creation for a certain "cost" and taking into account a number of "risks". Yet, it can be highlighted and considered as a separate component of the company's "competitive advantage". In general, as well as in the earlier study of Cooremans C., we proceed from the general principle of the superiority of the strategic logic over financial logic in making investment decisions in the area concerned [72,73].

Thus, the logic of our study aims to assess the possible impact of innovative processes of energy saving and energy efficiency improvement on the results of the company's strategic development. On the one hand, it is largely based on theoretical studies on the issue of strategic investment decisions $[74,75]$, and on the other hand, on research of various sources of non-energy benefits from investing in energy efficiency improvement [72,76-81]. However, firstly, in the above-mentioned studies, there is no mathematical formulation of the proposed approaches necessary for formalizing company's decision-making algorithms from the standpoint of energy efficiency improvement as a strategic priority for development. Secondly, the logic of the innovative potential developments used in the field of energy technologies to achieve strategic goals of the company's development is insufficiently disclosed.

\section{Conceptual Framework}

This study relies on the assumption that the approaches currently employed in respect of energy saving management and companies' energy efficiency improvement do not fully utilize the innovative potential of know-hows in the field of energy technologies to achieve development goals. The current situation poses a serious problem that hinders the development of companies in the context of the ongoing transition of the global economy to innovative development on the platform of the sixth wave of innovation. That is why, in order to address this problem, an innovative approach was developed based on the main ideas of the concept proposed for positioning of the energy saving and energy 
efficiency processes in the system of a company's management priorities. Its application, on the one hand, greatly complements and expands the possibilities of using previously obtained results in the framework of approaches developed by various researchers in order to overcome barriers to energy efficiency improvement [65,79-82]. On the other hand, it makes a certain contribution into the investigation of the problem of identification and assessment of strategic multiple or non-energy benefits of energy efficiency in a company $[83,84]$.

To build this approach, four tasks were addressed, which allowed achieving the goal of the study. First, the concept of positioning energy saving and energy efficiency processes in the company's management priorities system was proposed. Second, a mathematical statement of the task of energy saving and energy efficiency management in an industrial company in the context of its innovative development was worked out. It obviously takes into account various options for the positioning of energy saving and energy efficiency improvement. Third, a methodical approach was developed with respect to the conditions of building an energy saving and energy efficiency program in the company based on the adaptation of the main provisions of the proposed concept. And finally, fourth, it was experimentally tested to confirm the possibility of its practical use in solving applied problems of the development of companies.

When addressing the first task, it was proposed to consider positioning as a fundamental decision of the company's management about the place of energy saving and energy efficiency improvement in the system of its administrative priorities. It must be emphasized that this managerial decision should be made with due account for the purposes, requirements and results expected from the implementation of measures on energy saving and energy efficiency improvement [52,53]. This kind of positioning predetermines the possibility to consider the place and role of energy saving and energy efficiency in the system of management priorities of the company from different points of view, first, from the perspective of addressing the current operational problems of functioning of the company's energy utilities; second, from the perspective of one of possible vectors in solving tactical problems of increasing the efficiency of the company's production and business operations; and third, from the standpoint of one of the strategic areas of the company's development focused on the improvement of its competitiveness. These are the considerations that provide a basis for determining and justification of the role of energy saving and energy efficiency processes in the system of the company's management priorities. This largely predetermines further behavior of its executive management. In the developed classifier of positioning options, the options in question are presented as a set of interlinked characteristics (necessary investment volume, rate of return, sources of financing, expected results and possible effects, horizon of changes, scope and area of changes, etc.). These allow, first, to compare possible positioning alternatives and, second, to assess the consequences of choosing a certain option. For each positioning option, differences in the nature of the implemented vectors of the company's innovative development are provided depending on the level of their technological progressiveness. Special emphasis is placed on the possibility of reflecting promising trends in the development of innovative energy technologies in the proposed concept of energy saving and energy efficiency positioning.

As a result of the solution of the second problem, the purpose of mathematical formalization of the basic ideas of the positioning concept offered in terms of the theory of sets, was put forward. With this purpose in mind, the problem of energy saving and energy efficiency improvement management in the company was mathematically stated as a set of various mathematical ratios describing the behavior and properties of the process under study. This statement was supplemented by the rules of using such statement we introduced to determine the target function, which corresponds to the chosen option of energy saving and energy efficiency positioning, as well as to justify the priority tasks to be addressed in such positioning. Mathematical modeling is based on the use of basic procedures for energy saving and energy efficiency management in an industrial company. In the course of the research, it was presented in accordance with the methodology for implementing the energy management system based on the Plan-Do-Check-Act (PDCA) continuous improvement cycle. 
In solving the third task, the main provisions of the positioning concept were applied to the conditions of energy saving and energy efficiency program development. For this purpose, first, the principles of energy saving and energy efficiency management at the company in the context of its innovative development were formulated; second, the requirements to the use of management by objectives at the company were defined; and third, the algorithm of development and optimization of energy saving and energy efficiency improvement program was developed.

In addressing the fourth task, a machine tool and equipment factory was selected as an object to conduct experimental testing of the methodical approach developed. Such a choice of the object for the experimental testing of the approach developed is justified by the fact that machine tool building pertains to high-tech industries that widely employ advanced innovative solutions for the use of composite materials, power plants, digital technologies, etc., in the design and manufacturing of products. At the same time, machine tool building is an industry where energy costs constitute a significant portion in the cost of production, accounting for, according to various estimates, from $1.9 \%$ to $5.8 \%$ [85-87]. Therefore, the competitiveness of a machine tool building factory is largely determined by the influence of energy and innovation development factors.

The initial set of projects that can be offered for implementation within the framework of the program developed was generated, firstly, on the basis of the proposals received from the core production workshops and, secondly, on the basis of the actions developed following the results of the power audit conducted at the company. To assess the effectiveness of all proposed projects, a unified calculation methodology was used. To configure the program activities in respect of various positioning options, respective methodological support was proposed. The Gomori method was used to optimize many projects that may be included in the final energy saving and energy efficiency program. Its application is underlain by the possibility of finding an optimal plan of arrangement of various actions of the program to be developed when solving the integer programming tasks. The use of scenario modeling allowed to consider possible options of changing the company's competitive positions. It should be noted that competitive positions undergo the influence of optimization of the procedures for configuration of the energy saving and energy efficiency improvement program developed in the context of its innovative development.

It should be noted that the developed approach takes into account the logic of the currently used methodological approaches for identifying and evaluating the strategic multiple benefits of energy efficiency at a company. However, in comparison with other approaches used in the field under study, we compare the results of measures to improve energy efficiency with the achievement of the strategic goals of the company $[71,83]$. This comparison is ensured through the actualization of the innovative potential of energy technologies and is formalized in the form of a specific sequence of actions based on the generated mathematical models. Among the possible limitations of our approach, we can distinguish the following. First, at present, there is no generally accepted point of view in scientific circles regarding the set and content of possible multiple benefits [84]. Secondly, the effective application of the developed approach in practice requires a sufficiently high level of competence among decision-makers in the field of study [88]. Thirdly, informational support of the developed approach predetermines the need for sufficiently extensive statistical information in the company, which is often classified among the category of confidential information.

\section{Main Principles of the Concept of Positioning Energy Saving and Energy Efficiency Processes in the Company's Management Priorities System}

\subsection{Characteristics of Energy Saving and Energy Efficiency Positioning Options}

Problems of search for ways to activate the processes of energy saving and energy efficiency improvement in the companies' operations are considered in scientific studies from various perspectives. Particular attention among the works of various authors is paid to solution from the point of a comprehensive review of various barriers, limiting energy efficiency measures implementation in companies, combined with the rationale of various drivers application that encourage them to be 
overcome $[42,79-82,89,90]$. It is from this perspective that solution to the most important problems of energy efficiency improvement is considered in the publications of Thollander P., Cagno E., Trianni A. and several other researchers. We proceeded primarily from the nature of manifestation of two closely related types of barriers, "Economic" (Management support) and "Informative" (Management with real ambitions), according to the classification of Trianni A. [82]. In the study [90] they correspond to barriers of the "Behavioral" type (Other priorities, Lack of sharing the objectives, Lack of interest in energy efficiency interventions, etc.) and "Organizational" (Divergent interests and Low status of energy efficiency). Their manifestation largely determines an insufficiently high level of interest of company's management in the field of energy saving and energy efficiency measures implementation [49,91]. In the approach developed, we showed that the interest of top management in the problems of energy saving and energy efficiency will increase as their importance grows from the standpoint of the company's strategic goals achievement.

The proposed concept of energy saving and energy efficiency positioning is based on the existing differences between the tasks to be addressed by top management in the process of the company's development and reflection of those differences in the management decisions [52,92]. Possible differences include, first, the orientation in addressing the tasks in question towards various time horizons accompanied by various levels of uncertainty in the decision-making process. Second, the focus on using different levels of technological progressiveness of the company's innovative development measures, whose implementation is associated with a different level of investments required.

These differences place special demands on the company's energy saving and energy efficiency management when addressing problems at different levels. In view of the above, three options were identified for energy saving and energy efficiency positioning in the company.

1. Energy saving and energy efficiency improvement as a way of solving the current problems of the company's energy utilities. In the case of such positioning, energy saving and energy efficiency improvement are aimed at solving the problems associated with the elimination of existing deficiencies in the company's energy utilities. The result can be expressed as the reduction of energy consumption in the company in physical and monetary terms, reduction of the share of energy costs in the production of certain types of products, etc. In the case of such energy saving and energy efficiency positioning, the main objective is to solve current problems in the energy utility operations in order to improve the efficiency of the company's production and economic activity.

2. Energy saving and energy efficiency improvement as one of the possible ways to address tactical problems of increasing the efficiency of the company's production and business operations. In this case, energy saving and energy efficiency improvement are positioned as one of many areas of capital investment in order to improve the efficiency of the industrial enterprise. As competing options, for example, various fields of introduction of up-to-date production technologies, industrial equipment modernization, introduction of new materials, etc., can be considered. The results of investment in energy saving and energy efficiency development are manifested some time later in the future as the expected increase in the efficiency of the company's production and business operations. The best solutions are selected following the assessment of the comparative economic efficiency of various investment areas in the company. Given such positioning of energy saving and energy efficiency, the activity is mainly aimed at increasing the efficiency of the company's production and economic activity as a result of investments into the development of a respective production and technological base.

3. Energy saving and energy efficiency improvement as one of the strategic directions of the company's development focused on improving its competitiveness. In this case, energy saving and energy efficiency improvement are considered as a strategic direction for increasing the company's competitiveness. Given this kind of energy saving and energy efficiency positioning, the objective is to achieve the strategic goals of the company. 
All energy saving and energy efficiency improvement positioning options differ in terms of the level of technological progressivity of the company's innovative development vectors implemented. Therefore, the first option is viewed, above all, through the lens of ensuring the reliability and safety of current production activities. In contrast to the first one, the second positioning option shows a significantly higher level of expected results for innovative solutions. Those results are normally evaluated through the economic efficiency indicators. The third positioning option requires disruptive innovative solutions capable of bringing the company's business to a new level of development. Therefore, the need to take into account promising trends in the development of innovative energy technologies comes to the fore. The process of managing energy saving and improving energy efficiency itself becomes more complex than in the two previous positioning options. The final decision should be taken at the top management level of the company. It ought to be based on the understanding of the possible "results/costs" ratio for various options of energy saving and energy efficiency improvement positioning in the system of the company's management priorities and its financial capabilities.

It should be noted that focusing on the use of one of the options for positioning does not deny the possibility of implementing various measures considered as part of other options for positioning. On the contrary, in the decision-making process, we assume the continuity of options for positioning in the direction from the first to the third option. This means that the second option for positioning implies the possibility of measure implementation included in the first option, and the third option for positioning applies events, included in the second and the first. This continuity is a reflection of the real situation in which companies may experience problems at various levels, the solution of which can be based on different options for positioning of energy saving and energy efficiency improvement. This will be shown in more detail in Section 7 during optimization of the energy saving and energy efficiency improvement programs, based on measures, included in different options for positioning. Reorientation from one to another option for positioning requires informed decision making at the level of company management. For this, it was required, first of all, identification of the current option for positioning (Section 4.2) and, secondly, the need to use methodological approaches, which, depending on changes in the target guidelines of the company's management, can reorient the operational activity under consideration from one positioning option to another (Sections 5 and 6). It should be noted that the need to conduct a simultaneous assessment of the results on implementation of energy efficiency improvement measures is particularly significant in the Multiple Benefits project performance at the stage of 2019, especially from the perspective of not only operational but also strategic outcomes of a company. In addition, the need for increased attention to the functions of strategic planning is one of the arguments in the ongoing discussions on the revision of ISO 50001:2018 [93].

\subsection{Classifier of Energy Saving and Energy Efficiency Positioning Options}

To make administrative decisions in the company, we propose the developed classifier of energy saving and energy efficiency positioning options (Table 1). It presents the options mentioned as a set of interrelated characteristics that allow comparison of possible positioning options and assessment of the consequences of choosing a particular solution [52,92]. That is why the characteristics provided in the classifier include the necessary volume of investments, return thereon, sources of financing, expected results and possible effects, the horizon, volume and scope of changes and management methods. The whole range of the characteristics mentioned allows to identify the place of energy saving and energy efficiency in the management priorities system of the company's executives or, in other words, to assess their significance among all activity areas in terms of achieving the company's goals at a certain stage of its development. 
Table 1. The classifier of energy saving and energy efficiency positioning options in the company (source: compiled by the authors).

\begin{tabular}{|c|c|c|c|}
\hline \multirow[b]{2}{*}{$\begin{array}{l}\text { Characteristics of the Positioning } \\
\text { Options }\end{array}$} & \multicolumn{3}{|c|}{ Positioning Options } \\
\hline & $\begin{array}{l}\text { 1. Energy Saving and Energy Efficiency Improvement as a } \\
\text { Way of Solving the Current Problems of the Company's } \\
\text { Energy Utilities. }\end{array}$ & $\begin{array}{l}\text { 2. Energy Saving and Energy Efficiency Improvement } \\
\text { as One of the Possible Ways to Address Tactical } \\
\text { Problems of Increasing the Efficiency of the Company's } \\
\text { Production and Business Operations }\end{array}$ & $\begin{array}{l}\text { 3. Energy Saving and Energy Efficiency } \\
\text { Improvement as One of the Strategic Directions } \\
\text { of the Company Development }\end{array}$ \\
\hline Investment required & $\begin{array}{l}\text { The volume of investments is determined by the technical } \\
\text { condition of the company's energy utilities }\end{array}$ & $\begin{array}{l}\text { The volume of investments is determined by the project } \\
\text { parameters }\end{array}$ & $\begin{array}{l}\text { The volume of investments is determined by the } \\
\text { strategic goals of the company's development }\end{array}$ \\
\hline Return on investment & Short-term return on investment & Medium-term return on investment & Long-term return on investment \\
\hline Sources of financing & $\begin{array}{l}\text { External sources (subsidies and preferences from state } \\
\text { authorities) and/or internal sources (funds of current repair, } \\
\text { technical re-equipment and reconstruction programs, etc.). }\end{array}$ & $\begin{array}{c}\text { External sources (bank loans, funds of various } \\
\text { foundations and public organizations, investors, etc.) } \\
\text { and/or internal sources (special-purpose allocations from } \\
\text { profit). }\end{array}$ & $\begin{array}{c}\text { External (strategic domestic and foreign investors, } \\
\text { bank loans, funds of various foundations, etc.) and } \\
\text { internal sources (special-purpose allocations from } \\
\text { profit). }\end{array}$ \\
\hline Expected results & $\begin{array}{l}\text { Elimination of deficiencies identified in the energy supply of } \\
\text { production }\end{array}$ & $\begin{array}{l}\text { Improvement of the efficiency of the company's } \\
\text { production and economic activity }\end{array}$ & $\begin{array}{l}\text { Achievement of the company's strategic } \\
\text { development goals }\end{array}$ \\
\hline \multirow[b]{2}{*}{ Possible effects } & Effects characterizing the increase of production efficiency: & & \\
\hline & $\begin{array}{l}\text { 1. Lower specific energy consumption in } \\
\text { production processes. } \\
\text { 2. A higher ratio of energy produced to the energy consumed. } \\
\text { 3. Lower energy intensity of core and auxiliary production, } \\
\text { inter alia, of individual energy carriers. } \\
\text { 4. The lower share of energy costs in the cost of production. } \\
\text { 5. Lower pollutant emissions into the environment. } \\
\text { 6. Increased energy production from renewable sources. } \\
\text { 7. Reduction of energy consumption per } 1 \text { square meter of } \\
\text { the shop floor, etc. }\end{array}$ & $\begin{array}{l}\text { The effects characterize the increase in the efficiency of } \\
\text { investment activity aimed at the development of energy } \\
\text { technologies at the company: } \\
\text { 1. Growth of net present value. } \\
\text { 2. Increased profit and net profit margin. } \\
\text { 3. Reduced payback period of investments. } \\
\text { 4. Improved technical and economic performance of } \\
\text { the company, etc. }\end{array}$ & $\begin{array}{l}\text { The effects characterize the achievement of the } \\
\text { company's strategic development goals: } \\
\text { 1. Maintaining a leading position in a particular } \\
\text { market segment. } \\
\text { 2. Change in the business model of the company } \\
\text { 3. Entering new markets and the development of } \\
\text { new activities. } \\
\text { 4. Ensuring sustainable growth of the company's } \\
\text { capitalization, etc. }\end{array}$ \\
\hline Nature of innovations & $\begin{array}{l}\text { Local innovations at the level of individual subdivisions of the } \\
\text { company, aimed at the modernization of technological } \\
\text { processes, improvement of production management, etc. }\end{array}$ & $\begin{array}{l}\text { Large-scale innovations at the level of the company or its } \\
\text { individual subdivisions focused either on the production } \\
\text { of new products or on the use of new equipment, } \\
\text { advanced technologies and more advanced materials for } \\
\text { products manufactured by the company. }\end{array}$ & $\begin{array}{c}\text { Global innovations at the company level aimed at } \\
\text { achieving the company's strategic development } \\
\text { goals }\end{array}$ \\
\hline Change horizon & Short-term & Medium-term & Long-term \\
\hline Scope/area of change & Quite narrow/clearly defined area & Quite broad/changes depending on the expected result & $\begin{array}{l}\text { Global, depending on strategic objectives/changes } \\
\text { depending on the expected result }\end{array}$ \\
\hline Management methods & Project management & Program (project portfolio) management & Strategic management \\
\hline $\begin{array}{l}\text { Procedure for making decisions on } \\
\text { financing }\end{array}$ & $\begin{array}{l}\text { Development, approval, and financing of the works cost } \\
\text { estimates. }\end{array}$ & $\begin{array}{l}\text { Development and approval of the program budget by } \\
\text { senior management, phased funding of projects as the } \\
\text { planned activities of the program are actually } \\
\text { implemented. }\end{array}$ & $\begin{array}{l}\text { Drafting and approval of the development budget } \\
\text { by the company's owners, clarification of the funds' } \\
\text { volume for the next financial year, financing of } \\
\text { development areas in line with the achievement of } \\
\text { the performance planned. }\end{array}$ \\
\hline
\end{tabular}


The decision on the choice of the energy saving and energy efficiency positioning option in the company should be fixed and formalized in the hierarchy of corporate and administrative documents, including the overall strategy of the company, energy and innovation strategies, the company's energy saving and energy efficiency program, etc. It should be particularly noted that reasonably chosen and clearly formulated positioning is the most important prerequisite, which predetermines, above all, all subsequent activities of management in the planning, implementation, and monitoring of the policy developed in the field of energy saving and energy efficiency in the company.

\section{Mathematical Formulation of Managing Energy Saving and Energy Efficiency Improvement Problem in a Company under the Conditions of its Innovative Development}

\subsection{Mathematical Formulation of the Problem with Regard to Different Positioning Options}

The mathematical formulation of the problem involves managing energy saving and energy efficiency improvement under the conditions of innovative development. It should be formulated taking into account the selected positioning option and supplemented by a system of restrictions imposed by a number of internal and external factors' effect. Therefore, the target function of managing energy saving and energy efficiency improvement under the conditions of innovative development was defined for each positioning option. Moreover, possible limitations on the conditions of its implementation were established in the course of the study (Figure 1).

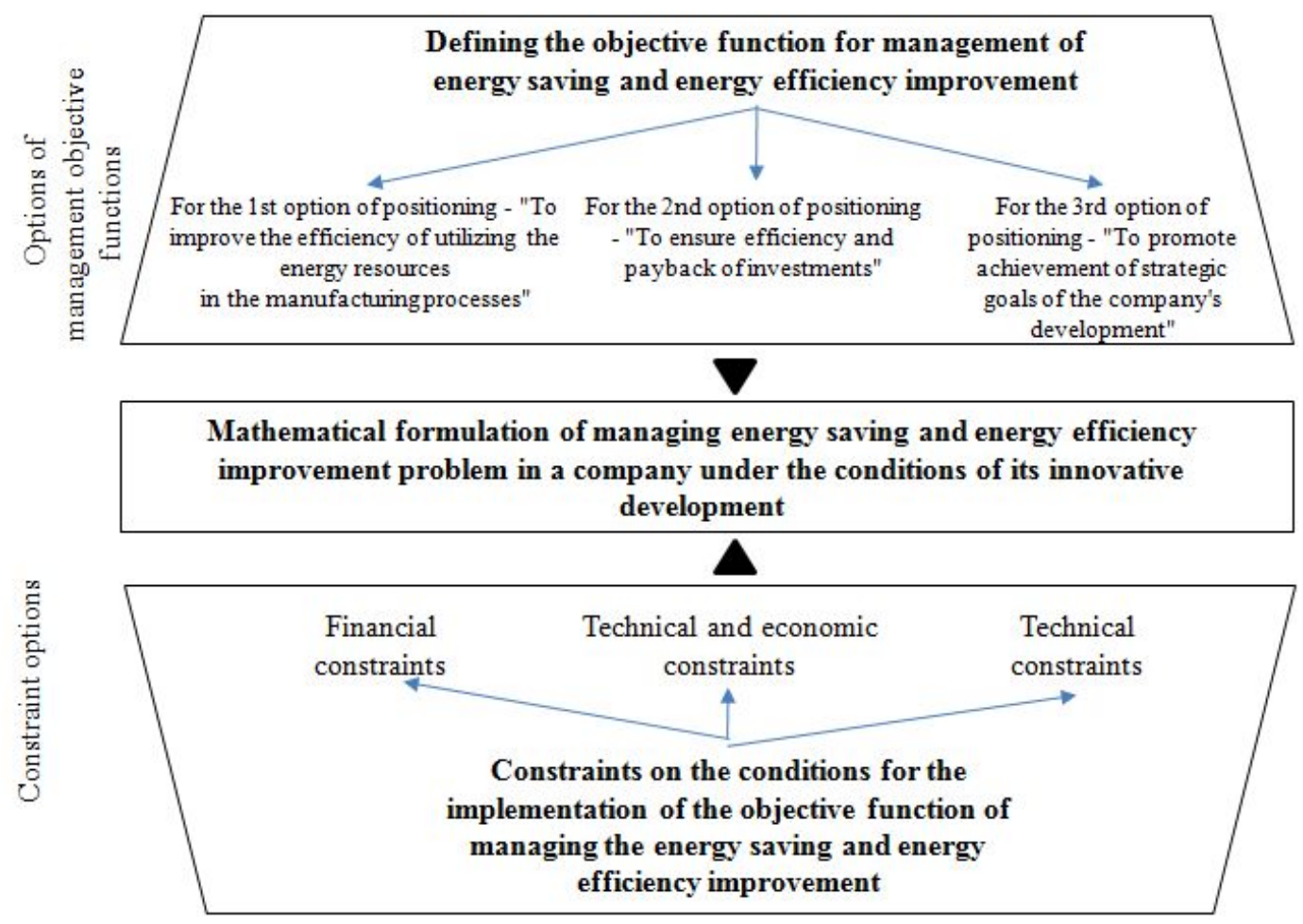

Figure 1. Defining the target function of energy saving and energy efficiency improvement and restrictions on the conditions of its implementation under different options of their positioning (source: compiled by the authors).

Further, the target management function shall be specified by using a mathematical model based on the core process of managing energy saving and energy efficiency improvement in an industrial enterprise (Figure 2) described in accordance with the principles of energy management system based on the Plan-Do-Check-Act (PDCA) continuous improvement cycle. The PDCA methodology discloses the sequence of the management actions on research process to achieve the goals. The control cycle begins with the planning of the process implementation. At the stage of the planned work completion, 
deviations from the planned result are determined, and the reasons are established for subsequent adoption of the necessary preventive measures. In relation to the problem of energy saving and energy efficiency improvement management for each stage of the PDCA cycle, a possible version of the mathematical formalization of the considered processes was proposed.

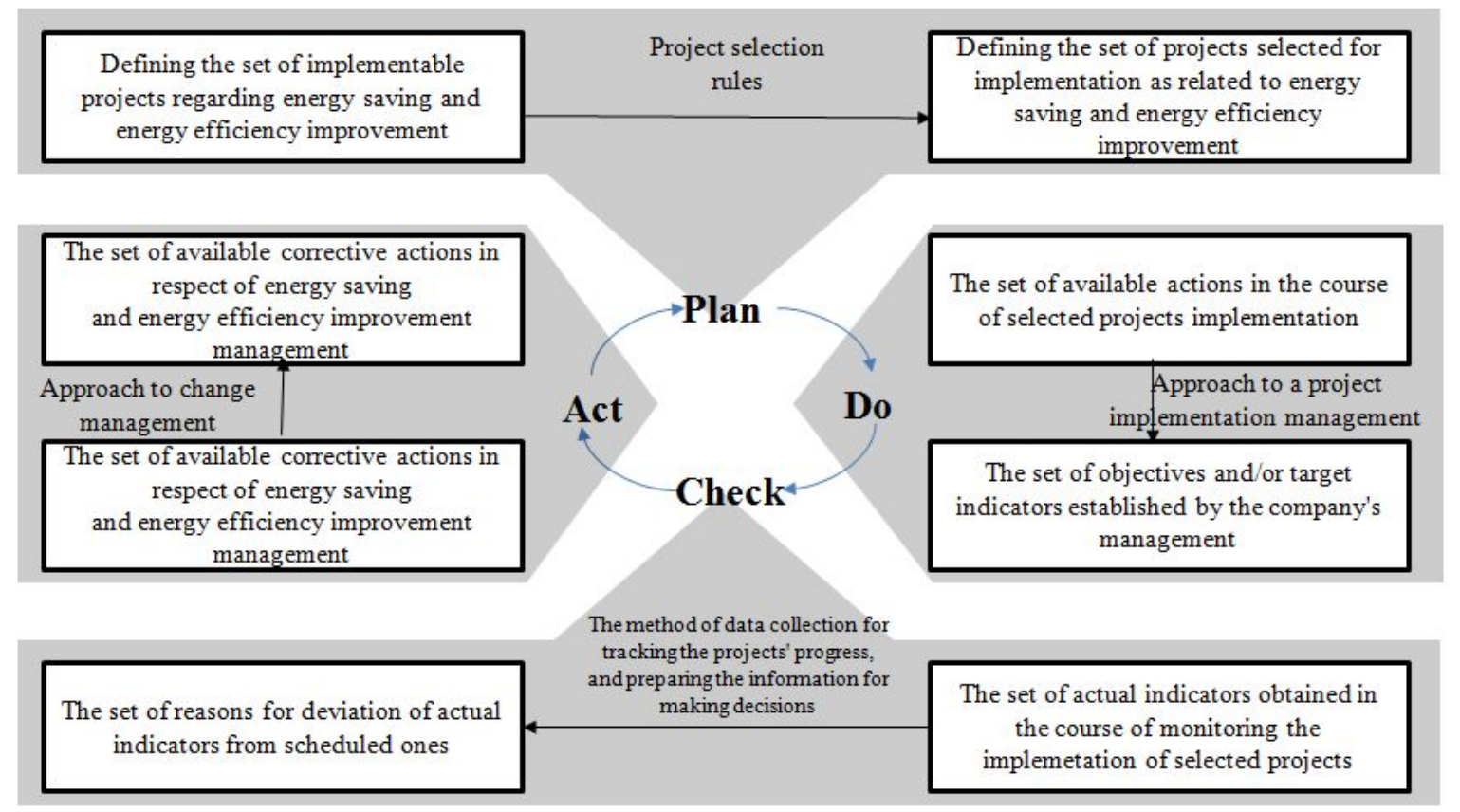

Figure 2. Basic process of managing energy saving and improvement of energy efficiency in the industrial company based on the "Plan-Do-Check-Act" continuous improvement cycle (source: compiled by the authors).

The key process element of the "Plan" block is the "project selection rules" that enable to narrow the set of implementable projects down to the set of selected projects. The selection rules are understood to be a set of criteria for selection of projects. It is obvious that a large number of criteria may exist, so the problem to be solved in this block can be represented as follows:

$$
I, X(I) \stackrel{\delta}{\rightarrow} \widetilde{I}, X(\widetilde{I}) \mid O(\widetilde{I}) \in O
$$

where $I$ is a set of implementable energy saving and energy efficiency improvement projects that includes projects, each of which alone has the potential to be implemented in the company; $X(I)$ is the technological interconnection matrix of projects from the set of initial projects $I ; \delta$-is a designation of available project selection rules that make possible the transition from the set $I$ to the set $\widetilde{I} ; \vec{I}$ is the set of selected projects, which will ensure the achievement of the goals established by the company's management; $X(\widetilde{I})$ is the technological interconnection matrix of projects from a variety of selected projects $I$, such that it does not contain alternative projects; mutually complementary projects are accepted or rejected at the same time, and the emergence from mutually-influencing projects is maximized; $O(\widetilde{I})$ is the internal and external constraints imposed on the implementation of the set of selected projects $\widetilde{I}$ belonging to $O$ is the acceptable set of values of all possible constraints.

From the standpoint of management, the rules for selecting projects $\delta$ should be regarded as a certain function reflecting the objectives of the company's management when drafting a set of energy saving measures for subsequent implementation, i.e., as a target function. The target function's optimal value should be searched for in the set of implementable projects $I$. The following can be the examples of a target function: a maximum possible reduction of annual energy consumption throughout the company while retaining the fixed amount of production output [94-96], reducing the cost of energy 
supply of the major production machines $[97,98]$, reducing energy costs for supporting processes (heating, ventilation, lighting, etc.) [99], increasing the company's profits by lowering share of energy costs in the cost of production [100,101], accessing new markets through the use of energy efficient technologies [102-104], etc. It is clearly necessary to keep in mind a number of constraints like resource allocation, efficiency of projects [105-107], etc., beyond the rules of project selection.

The key process element for the implementation of the selected projects in the "Do" block is the approach to project implementation management. The problem addressed in this block can be represented in the following mathematical form:

$$
R(\widetilde{I}), X(\widetilde{I}) \stackrel{\mu}{\rightarrow} C(\widetilde{I}) \mid O(\widetilde{I}) \in O
$$

where $R(\widetilde{I})$ is the set of acceptable actions in the course of selected projects $\widetilde{I}$ implementation; $\mu$ is the designation of possible approach to project implementation management that makes it possible to represent the set $R$ in the set $C ; C(\widetilde{I})$ is the set of goals and/or target indicators to be achieved by the end of projects $\widetilde{I}$ implementation.

At the same time, one of the mathematical models for decision making can be considered as the possible approach to implementation of the projects $\mu$. For example, the preferences of a manager authorized to make decisions on implementation of projects within the framework of rational behavior base model may be described as a function of utility or a preference [52,108]. It is quite obvious that the degree of the company management's involvement in the project implementation management process depends on the existing management culture in the company $[109,110]$, expressed in the system of responsibility and authority assignment. This, however, can be transformed in accordance with the positioning of energy saving and energy efficiency improvement.

It should also be noted that the developed formulations (Equations (1) and (2)) take into account the technological relationship between various projects with the following features: first, mutually exclusive projects, where the implementation of one of these projects makes it impossible or impractical to implement the other(s); secondly, complementary projects, the implementation of which requires them to be accepted or rejected in parallel; thirdly, interdependent projects, joint implementation of which generates emergent features that are not inherent to any of them separately. At the same time, within formulations (Equations (1) and (2)), such conditions are established for selecting events whereby the set of selected projects does not contain mutually exclusive projects. Complementary projects are accepted or rejected in parallel, and emergent features of interdependent projects are maximized.

The determining elements of the monitoring process in the "Check" block are, firstly, the method of data collection for tracking the projects' progress and, secondly, the algorithm of preparing the information for making decisions. The problem addressed in this block can be represented in the following mathematical form:

$$
P^{\prime}(\widetilde{I}) \stackrel{v}{\rightarrow} W(\widetilde{I}) \mid P^{\prime}(\widetilde{I}) \notin P(\widetilde{I})
$$

where $P^{\prime}(\widetilde{I})$ is the set of actual indicators obtained in the course of monitoring the implementation of selected projects $\widetilde{I} ; v$ is designation of a possible data collection method to control implementation of projects and preparation of information for decision making that will enable displaying the set $P^{\prime}$ inside $W ; W(\widetilde{I})$ is the set of reasons for the deviation of actual indicators from scheduled ones; $P(\widetilde{I})$ is the set of target indicators to be achieved in the course of implementation of the selected projects set $\widetilde{I}$.

The key element of the corrective actions process in the "Act" block is the approach to change management. This approach enables to directly determine the situations when a change has to be commenced as regards the following: first, the selection rules for projects $\delta$ when scheduling energy saving activities; second, the developed approach to the management of projects $\mu$ implementation; third, data collection and preparation methods in the course of monitoring $v$; fourth, under alternative 
conditions of energy saving and energy efficiency improvement management. The problem addressed in this block can be represented in the following mathematical form:

$$
K(W) \stackrel{\lambda}{\rightarrow} K
$$

where $K(W)$ is the set of available corrective actions in respect of energy saving and energy efficiency improvement management that are dependent on the results $W$ obtained during monitoring; $\lambda$ is designation of a potential approach to change management that enables representing the set $K$ in $K ; K$ is the set of the selected corrective actions in respect of energy saving and energy efficiency improvement management.

\subsection{Managing the Changes in Energy Saving and Energy Efficiency Improvement Processes}

With regard to the suggested approach, corrective actions can be taken in the following areas. First, through a system of objectives and their decomposition among different structures; second, through the composition of divisions that are interconnected by certain relations; third, through distribution of tasks and functions across all divisions; fourth, through allocation of responsibilities, rights and authority within the organization; fifth, through the information flow and the document flow used; sixth, through the behavioral attitudes of staff continuously entering into various mutual relations to address development objectives [110-113]. The area and the scale of corrective actions as regards the management of energy saving and energy efficiency improvement, as well as the extent of changes in the behavioral system of staff relations, will be largely determined by the selected option of positioning (Figure 3). Reviewed trends on changes management develop ideas realized in the Cooremans C. study [114] where the organizational context for making investment decisions in energy efficiency improvement is examined in terms of structure, procedures, strategy and organizational culture.

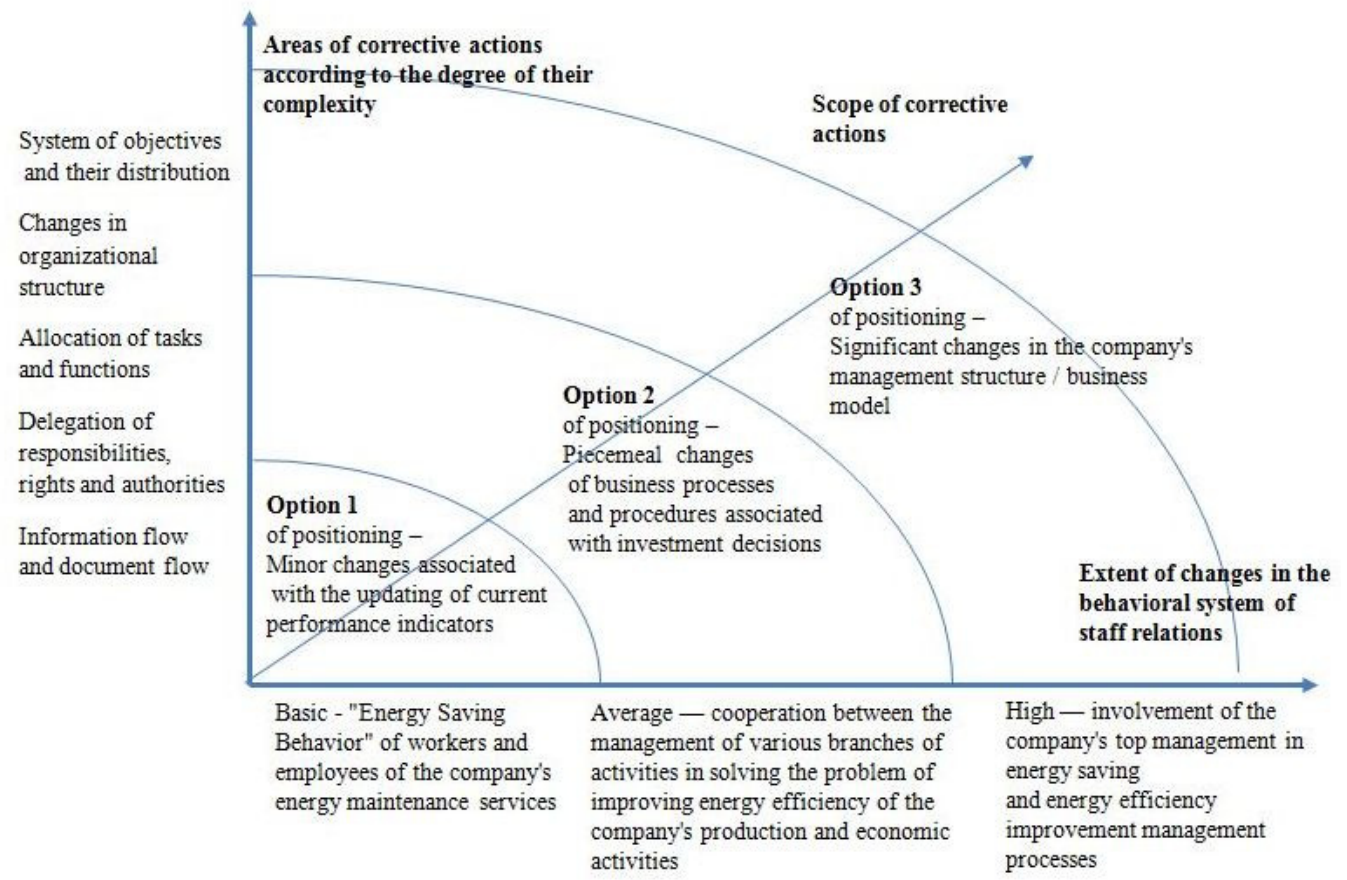

Figure 3. Potential changes in the behavioral system of staff relations at different options of the positioning of energy saving and energy efficiency improvement (source: compiled by the authors).

Following the corrective actions, the energy saving and energy efficiency improvement processes, which are considered to be one of the priorities of the company development, have to be fulfilled to the fullest extent. 
Let us name the above-mentioned set of ratios (Equations (1)-(4)) mathematical formulation of energy saving and energy efficiency improvement management problem at the industrial enterprise under the conditions of its innovative development, and represent it as follows (Equation (5)):

$$
\left\{\begin{array}{c}
I, X(I) \stackrel{\delta}{\rightarrow} \widetilde{I}, X(\widetilde{I}) \mid O(\widetilde{I}) \in O \\
R(\widetilde{I}), X(\widetilde{I}) \stackrel{\mu}{\rightarrow} C(\widetilde{I}) \mid O(\widetilde{I}) \in O \\
P^{\prime}(\widetilde{I}) \stackrel{v}{\rightarrow} W(\widetilde{I}) \mid P^{\prime}(\widetilde{I}) \notin P(\widetilde{I}) \\
K(W) \stackrel{\lambda}{\rightarrow} K
\end{array} .\right.
$$

Selection of the target function, which was designated as $(\delta, v, \lambda)$, and its supplementation with system of constraints according to the appropriate option of positioning will enable simulating various scenarios and explore alternatives. Thus, the problem of energy saving and energy efficiency improvement management in the implementation of company's operational, tactical and strategic objectives can be addressed. Deterministic and stochastic models of mathematical optimization [115-117] can be used in the represented mathematical formulation. Their use will depend on the nature of internal and external constraints for addressing the problems of energy saving and energy efficiency improvement management at the company. In the case where constraints are not dependent on the random vector of external parameters, deterministic methods may be used. Under high uncertainty conditions, it is more preferable to use stochastic optimization methods, which include the entire class of optimization algorithms applying random processes described through probability distributions in the process of searching for an optimum.

\section{Application of the Positioning Theory's Main Provisions to Energy Saving and Energy Efficiency Improvement Program's Development Conditions}

\subsection{Principles and Requirements for Building an Energy Saving and Energy Efficiency Improvement Program}

The approach to drafting the program of energy saving and energy efficiency improvement being developed implies ensuring the most efficient use of innovative solutions to achieve the objectives of company development. The logic of its building determined the need to develop, first, the principles of energy saving and energy efficiency management at the company in the context of its innovative development; second, the requirements to the use of management by objectives at the company; and third, the algorithm of development and optimization of energy saving and energy efficiency improvement program.

The following were identified as the most important principles of the approach being developed. First, consideration of the high degree of mutual influence of energy saving and energy efficiency improvement processes and innovative development processes [118]; second, the need for coordination of managerial decisions related to energy saving and energy efficiency improvement, on the one hand, and related to the innovative development, on the other [53,92,119]; third, active participation of company's management in the management of the processes under consideration [52,91,120,121].

The prevailing approaches to the management of energy saving and energy efficiency improvement of an industrial enterprise are based, as a rule, on standard solutions defined by the P2M and PMI program management standards [94]. However, their adaptation to the problem under study has required an expansion of the requirements for building the approach under development. We merged them into two following groups. The first group of requirements is related to the innovative nature of the measures that should be focused on achieving the goals of the company's development under various options of energy saving and energy efficiency improvement positioning. In line with these requirements, first, the place and role of the energy saving and energy efficiency improvement measures in the system of priorities for the innovative development of the company has to be considered when planning, implementing and monitoring their efficiency; second, the indicators featuring the company's value and competitiveness growth, access to new markets, etc., shall be used as target indicators 
of the program along with the conventional indicators of energy resource use efficiency; third, the potential correlation of the program being developed with other programs, including, for example, manufacturing program, investment program, etc. shall be highlighted. These requirements were examined in more detail in the study by Melnik et al. [122], which sets out the features of methodological approach creation with the aim of setting up indicators for managing innovative activities in order to achieve strategic development goals.

The second group of requirements for the approach under development is related to reflecting the ways of the company's innovative development under the influence of scientific and technological advancements in the company's activity area. They predetermine the need to consider the following: first, the possibility of using scientific, technical and commercial cooperation with other market players to supplement deficient expertise $[100,123]$; second, the possibility of using mechanisms of government support for the priority areas of innovative development and innovative modernization of the national economy [124-126]; third, ways of intensifying export activities and entering new markets by improving the competitiveness of manufactured goods resulting from implementation of series of measures on energy saving and energy efficiency improvement [52,127]. Fulfillment of these requirements will enable us to significantly expand the set of technological ways of company's innovative development in the course of energy saving and energy efficiency improvement program building. It will further make it possible to increase the efficiency of human labor use beyond the rational use of energy resources.

\subsection{Stages of the Company's Energy Saving and Energy Efficiency Improvement Program Building Based on the Positioning Theory}

The principles created and the requirements developed have underpinned the development of the sequence of energy saving and energy efficiency improvement program in the context of the company's innovative development. It includes four major stages of the works performed (Figure 4).

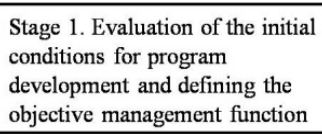
company development programs

Stage 4. Resource allocation of th program and determining the organizational conditions for its implementation.

Figure 4. The main stages of building the program of energy saving and energy efficiency improvement of the company in the context of its innovative development (source: compiled by the authors).

The first stage involves the positioning of energy saving and energy efficiency improvement in the context of innovative development, defining the objective management function and constraints on the conditions for its implementation in accordance with the positioning performed. The solution to these problems is based on research to identify the objectives of the company management and to determine the priority of energy saving and energy efficiency improvement in the company's management system. On the basis of this work's results, the conscious decision of the top management to change the system of management priorities was made. It allows to formulate the objectives of the program and determine the potential contribution of energy saving and energy efficiency improvement to the company's innovative development [52].

The second stage assumes the accomplishment of a series of works on optimization of program activities' composition by defining the extremum of management's objective function. Following their implementation, a list of program activities should be drafted out of the entire set of implementable projects.

The third stage provides for the implementation of procedures of coordination of the taken decisions with other programs of company development that are being implemented. It is aimed at identifying the potential impact of the program being developed on the implementation of other programs of company development, including, for example, the manufacturing program, innovative development program and a number of others. 
The fourth stage discloses the resource allocation of the program and provides for the creation of appropriate organizational conditions for its implementation. Where applicable, a set of organizational mechanisms should be developed to maintain and support the implementation of the program. Among other measures, it includes measures to reduce the company expenditures and to overcome the opposition to implemented organizational changes. All arrangements are aimed at creating the most favorable conditions for the implementation of the drafted program.

\section{Methods and Empirical Study}

\subsection{Mathematical Formulation of the Optimization Problem with Regard to Different Positioning Options}

Experimental testing of the developed approach was carried out in relation to the various positioning options defining the role of the energy saving and energy efficiency improvement process in the system of company development priorities management. The objective for building the program was determined, and mathematical formulation of the problem for each option of energy saving and energy efficiency improvement positioning was developed in accordance with the composition of works at the first stage of the developed sequence of steps. As a target priority of the program implementation with regard to the first option of positioning, the maximum increase in the efficiency of energy resources use in the process of production activities was determined. The constraints in the event of such formulation of the problem are related to the limit of the allocated funding. In this case, the mathematical formulation of the problem can be presented as follows:

$$
\left\{\begin{array}{c}
f(\delta)=\sum_{i=1}^{N} E_{i} X_{i} \rightarrow \max \\
O \Leftrightarrow O_{1} \\
O_{1}: i=\sum_{i=1}^{N} S_{i} X_{i} \leq L \\
X_{1}, X_{2}, X_{3}, \ldots, X_{N} \in\{0 ; 1\}
\end{array},\right.
$$

where $f(\delta)$ is the objective function; $\mathrm{O}$ is the system of constraints, comprising $\mathrm{O}_{1} ; \mathrm{X}$ is the vector of controlled variables, describing the final composition of the program, $X_{i}$ takes the value " 1 " upon inclusion of the $i$-th project in the program, otherwise it returns " 0 "; $E_{i}$ is the savings stemming from the $\mathrm{i}$-th project, USD; $\mathrm{L}$ is the limit of allocated funds, USD; $\mathrm{S}_{\mathrm{i}}$ amount of investment in i-th project, USD; $\mathrm{N}$ is the number of projects in the set of initial activities, which can be implemented at the company.

In the second option of positioning, energy saving and energy efficiency improvement are considered as one of the possible areas for investment. Within this formulation, the selection criterion will be the return on investment with the shortest payback period of projects. In this case, the mathematical formulation of the problem can be presented as follows:

$$
\left\{\begin{array}{c}
f(\delta)=\sum_{i=1}^{N} N P V_{i} X_{i} \rightarrow \max \\
O \Leftrightarrow O_{1} \\
O_{1}: P B_{i} \leq t ; i \in\{1, \ldots, N\} \\
X_{1}, X_{2}, X_{3}, \ldots, X_{N} \in\{0 ; 1\}
\end{array},\right.
$$

where $f(\delta)$ is the target function; $\mathrm{O}$ is the system of restrictions including $\mathrm{O}_{1}$ is the specific restrictions; $\mathrm{X}$ is the vector of controllable variables describing the final composition of the program; $X_{i}$ takes value " 1 " if we include $i$-th project in the program, otherwise it returns " 0 "; $\mathrm{NPV}_{\mathrm{i}}$ is the net present value of $i$-th project, $U S D ; \mathrm{PB}_{\mathrm{i}}$ is the payback period of $\mathrm{i}$-th project, years; $\mathrm{t}$ is the standard payback period of investment projects, established at the enterprise; $\mathrm{N}$ is the number of projects in a set of original activities that can be implemented at the enterprise. 
The third option of positioning considers energy saving and energy efficiency improvement from the standpoint of achieving the company's strategic goals. In this case, the mathematical formulation of the problem can be presented as follows:

$$
\left\{\begin{array}{c}
f(\delta)=\sum_{i=1}^{N} F_{i} X_{i} \rightarrow \max \\
O \Leftrightarrow O_{1} \vee O_{2} \\
O_{1}: X_{i}=1 \forall i: F_{i} \geq 80 \\
O_{2}: P B_{i} \leq k ; i \in\{1, \ldots, N\} \\
X_{1}, X_{2}, X_{3}, \ldots, X_{N} \in\{0 ; 1\}
\end{array},\right.
$$

where $f(\delta)$ is the target function; $\mathrm{O}$ is the system of restrictions including $\mathrm{O}_{1}, \mathrm{O}_{2}$ is the specific restrictions; $X$ is the vector of controllable variables describing the final composition of the program; $X_{i}$ takes value " 1 " if we include $i$-th project in the program, otherwise it returns " 0 "; $F_{i}$ is the project's influence degree on achievement of the company's strategic goals, $\% ; \mathrm{PB}_{\mathrm{i}}$ is the payback period of $\mathrm{i}$-th project, years; $\mathrm{k}$ is the standard payback period of strategic investment projects, established at the enterprise; $\mathrm{N}$ is the number of projects in a set of original activities that can be implemented at the enterprise.

\subsection{Methods of Program Activities Grouping with Respect to Various Options of Positioning}

At the second stage of the sequence of works developed by the authors, the initial set of projects was considered. It may be suggested for implementation as a part of the program being developed. This set was built based on: Equation (1) the suggestions from main production workshops and Equation (2) the activities developed following the results of energy audit that had been carried out at the company (Table 2). Four parameters were defined for each activity. They included investment costs, reduction of company's energy consumption in terms of value resulting from the implementation of the suggested activity and its impact on the achievement of the company's strategic objectives.

The above-described problems, represented in mathematical formulations 6-8, can be referred to as problems of linear programming. The use of the simplex algorithm has become the most widely used method in addressing such problems [128]. The drawback of its application to the problem under consideration is manifested in the possibility of obtaining a fractional value as a solution result. Hence, it is more preferable to use such methods, which enable getting the optimal solution of the problem, the coordinates of which are integers. Branch and bound algorithm and Gomori's cutting plane algorithm can be particularly named among these methods. The branch and bound method is widely used when addressing such tasks of integer programming where the number of unknowns is either small or the requirements of being integers do not relate to all the unknowns [129]. Gomori's cutting plane algorithm is a more general method of solving integer programming problems whereby it is possible to obtain the optimal plan after a finite number of iterations or verify that the problem has no solutions [48]. That is why the Gomori method was chosen to solve the problem under consideration. Following the calculations made based on this algorithm's application, the set of projects was obtained that are eligible for inclusion in the final energy saving and energy efficiency improvement program (Table 3). 
Table 2. A consolidated list of suggestions received to be included in the company's Energy Saving and Energy Efficiency Improvement program (source: compiled by the authors based on the company data).

\begin{tabular}{|c|c|c|c|c|}
\hline № & Project Name & Investment Costs, USD ’000 & $\begin{array}{l}\text { Reduction of Energy Consumption in } \\
\text { Terms of Value, '000 USD/year }\end{array}$ & $\begin{array}{l}\text { Impact on the Achievement of } \\
\text { Strategic Objectives }\end{array}$ \\
\hline 1. & $\begin{array}{l}\text { Changing the option of cooperation with a sales company for all workshops of the company, } \\
\text { including the transition from a single-rate tariff to a tariff differentiated by two time zones of the } \\
\text { day. }\end{array}$ & 0.00 & 16.67 & Weak \\
\hline 2. & Installation of energy-saving lamps in production divisions. & 83.33 & 20.00 & Weak \\
\hline 3. & Installation of inlet ventilation and air curtains for gates in production divisions. & 83.33 & 0.00 & Weak \\
\hline 4. & Main repair of a cooling tower of a circulating water station. & 50.00 & 24.17 & Weak \\
\hline 5. & $\begin{array}{l}\text { Installation of air conditioning devices in certain areas and offices, partial replacement of heating } \\
\text { appliances with modern ones(convectors with enhanced heating power instead of cast iron } \\
\text { radiators). }\end{array}$ & 133.33 & 0.00 & Weak \\
\hline 6. & $\begin{array}{l}\text { Actions to improve the production and engineering infrastructure: repair of the roof of } \\
\text { manufacturing building, redecorating the premises with the installation of plastic windows, repair } \\
\text { of the storm drain, repair of the fence and fencing of the territory's perimeter fence around the } \\
\text { entrance gate. }\end{array}$ & 333.33 & 0.00 & Weak \\
\hline 7. & Introduction of automated technology for high-precision cutting of sheet materials. & 1166.67 & 50.00 & Moderate \\
\hline 8. & $\begin{array}{l}\text { Assessment of usable groundwater resources at the company's water supply point, obtaining a } \\
\text { water use license, drilling two artesian wells. }\end{array}$ & 583.33 & 8.33 & Weak \\
\hline 9. & $\begin{array}{l}\text { Designing the automated system of electric power control and metering for all workshops of the } \\
\text { company }\end{array}$ & 500.00 & 0.00 & Weak \\
\hline 10. & $\begin{array}{l}\text { Avoiding no-load (idle) operation of equipment at welding, soldering and hydrostatic testing areas } \\
\text { of the production shop during preparation for a working shift. }\end{array}$ & 0.00 & 5.00 & Weak \\
\hline 11. & Fulfillment of the established electric power consumption limits in the production workshop. & 0.00 & 16.67 & Weak \\
\hline 12. & Mothballing of the unused production building. & 50.00 & 20.00 & Weak \\
\hline 13. & Adjustment of steam consumption. & 10.00 & 4.00 & Weak \\
\hline 14. & Switching off streetlights to energy saving lamps in the territory of the workshop's production site. & 5.00 & 3.33 & Weak \\
\hline 15. & Switching the air supply (HVAC system) to rotary-screw compressors. & 166.67 & 6.00 & Weak \\
\hline 16. & $\begin{array}{l}\text { Replacement of universal lathes (machine tools) with numerically controlled machining centers } \\
\text { (CNCs) featuring better operating and resource consumption properties. }\end{array}$ & 833.33 & 16.67 & Strong \\
\hline 17. & Installation of heating water recirculation system on hot-water boilers in a boiler room. & 41.67 & 3.00 & Weak \\
\hline 18. & $\begin{array}{l}\text { Replacement of lamps with incandescent light bulbs with energy saving lamps with fluorescent } \\
\text { light bulbs. }\end{array}$ & 25.00 & 2.50 & Weak \\
\hline 19. & Utilizing a heat exchanger for preheating in a hot water supply system. & 16.67 & 2.00 & Weak \\
\hline 20. & Installation of capacitor units for reactive power compensation with automated control. & 33.33 & 2.50 & Weak \\
\hline 21. & Installation of dust collecting ventilation device. & 33.33 & 0.00 & Weak \\
\hline 22. & The package of measures for heat insulation of buildings and structures. & 200.00 & 0.00 & Weak \\
\hline 23. & Automation of casting patterns fabrication method with the use of self-hardening blends. & 1666.67 & 41.67 & Strong \\
\hline
\end{tabular}


Table 3. The final arrangement of the program's activities for different positioning options (source: compiled by the authors).

\begin{tabular}{|c|c|c|c|}
\hline \multirow[b]{2}{*}{ Project No. } & \multicolumn{3}{|c|}{ Program Composition by Different Options } \\
\hline & $\begin{array}{l}\text { 1. Energy Saving and Energy Efficiency } \\
\text { Improvement as a Way of Solving the } \\
\text { Current Problems of the Company's } \\
\text { Energy Utilities. }\end{array}$ & $\begin{array}{l}\text { 2. Energy Saving and Energy Efficiency } \\
\text { Improvement as One of the Possible Ways to } \\
\text { Address Tactical Problems of Increasing the } \\
\text { Efficiency of the Company's Production and } \\
\text { Business Operations }\end{array}$ & $\begin{array}{l}\text { 3. Energy Saving and Energy } \\
\text { Efficiency Improvement as } \\
\text { One of the Strategic Directions } \\
\text { of the Enterprise Development }\end{array}$ \\
\hline 1. & + & + & + \\
\hline 2. & + & + & + \\
\hline 4. & + & + & + \\
\hline 5. & + & - & + \\
\hline 6. & + & - & + \\
\hline 7. & - & - & + \\
\hline 8. & - & - & - \\
\hline 12. & + & + & + \\
\hline 13. & + & + & + \\
\hline 14. & + & + & + \\
\hline 15. & + & - & - \\
\hline 16. & - & - & + \\
\hline 17. & + & - & - \\
\hline 18. & + & - & + \\
\hline 19. & + & - & - \\
\hline 20. & + & - & - \\
\hline
\end{tabular}

The results of the accomplished optimization of energy saving and energy efficiency improvement program under various positioning options are shown in Table 4.

\subsection{Analysis of the Obtained Results}

Pursuant to the analysis of the results obtained, the set of program activities resulting from the performed optimization differs considerably for each of the three positioning options under consideration. Thus, 18 out of 23 suggested activities were selected and included in the program with regard to the first positioning option. Investments amount for their implementation will make USD $1.265 \mathrm{mln}$. The presented set of program activities will enable saving USD 0.134 million/year. Energy costs will be reduced by $4.8 \%$.

Resulting the optimization 8 out of 23 suggested activities were selected and included in the program with regard to the second positioning option. Investments amount for their implementation will make USD $0.198 \mathrm{mln}$. NPV over the 5 years will amount to USD $0.155 \mathrm{mln}$ at the discount rate of $20 \%$. Energy costs will be reduced by $4.2 \%$.

Finally resulting the optimization, 16 out of 23 suggested activities were selected and included in the program with regard to the third positioning option. Investments amount for their implementation will make USD $4.467 \mathrm{mln}$. The expected cost savings will amount nearly USD 0.233 million/year, and energy costs will be reduced by $8.1 \%$. 
Table 4. The optimization results of energy saving and energy efficiency improvement program under various positioning options (source: compiled by the author).

\begin{tabular}{|c|c|c|c|}
\hline $\begin{array}{l}\text { Option of } \\
\text { Positioning }\end{array}$ & $\begin{array}{l}\text { 1. Energy Saving and Energy Efficiency } \\
\text { Improvement as a Way of Solving the } \\
\text { Current Problems of the Company's } \\
\text { Energy Utilities }\end{array}$ & $\begin{array}{l}\text { 2. Energy Saving and Energy Efficiency } \\
\text { Improvement as One of the Possible Ways to } \\
\text { Address Tactical Problems of Increasing the } \\
\text { Efficiency of the Company's Production and } \\
\text { Business Operations }\end{array}$ & $\begin{array}{l}\text { 3. Energy Saving and Energy } \\
\text { Efficiency Improvement as } \\
\text { One of the Strategic Directions } \\
\text { of the Enterprise Development }\end{array}$ \\
\hline $\begin{array}{l}\text { Program } \\
\text { drafting } \\
\text { objectives }\end{array}$ & $\begin{array}{l}\text { Maximizing the utilizing efficiency of } \\
\text { energy resources in the course of } \\
\text { manufacturing with respect to: first, the } \\
\text { budget limit of USD 1.6 million; second, all } \\
\text { activities aimed at improving the working } \\
\text { conditions of the company's employees, } \\
\text { which should be implemented to ensure } \\
\text { compliance with regulatory requirements. }\end{array}$ & $\begin{array}{c}\text { Payback of investments within a period of no more } \\
\text { than five years. }\end{array}$ & $\begin{array}{l}\text { Contributing to the achievement } \\
\text { of the strategic objective of the } \\
\text { company, i.e., substitution of } \\
\text { foreign comparable goods by } \\
\text { reducing the cost of the } \\
\text { equipment being developed } \\
\text { while optimizing its design. }\end{array}$ \\
\hline $\begin{array}{l}\text { Formulation } \\
\text { of the } \\
\text { problem }\end{array}$ & $\left\{\begin{array}{c}f(\delta)=\sum_{i=1}^{N} E_{i} X_{i} \rightarrow \max \\
O \Leftrightarrow O_{1} \\
O_{1}: i=\sum_{i=1}^{N} S_{i} X_{i} \leq L \\
X_{1}, X_{2}, X_{3}, \ldots, X_{N} \in\{0 ; 1\}\end{array}\right.$ & $\left\{\begin{array}{c}f(\delta)=\sum_{i=1}^{N} N P V_{i} X_{i} \rightarrow \max \\
O \Leftrightarrow O_{1} \\
O_{1}: P B_{i} \leq t ; i \in\{1, \ldots, N\} \\
X_{1}, X_{2}, X_{3}, \ldots, X_{N} \in\{0 ; 1\}\end{array}\right.$ & $\left\{\begin{array}{c}f(\delta)=\sum_{i=1}^{N} F_{i} X_{i} \rightarrow \max \\
O \Leftrightarrow O_{1} \vee O_{2} \\
O_{1}: X_{i}=1 \forall i: F_{i} \geq 80 \\
O_{2}: P B_{i} \leq k ; i \in\{1, \ldots, N\} \\
X_{1}, X_{2}, X_{3}, \ldots, X_{N} \in\{0 ; 1\}\end{array}\right.$, \\
\hline $\begin{array}{l}\text { Parameters of } \\
\text { the program }\end{array}$ & $\begin{array}{l}18 \text { of } 23 \text { activities have been selected } \\
\text { Investments-USD } 1.265 \text { million }\end{array}$ & $\begin{array}{l}8 \text { of } 23 \text { activities have been selected } \\
\text { Investments-USD } 0.198 \text { million }\end{array}$ & $\begin{array}{l}16 \text { of } 23 \text { activities have been } \\
\text { selected } \\
\text { Investments-USD } 4.467 \text { million }\end{array}$ \\
\hline $\begin{array}{l}\text { Expenditures } \\
\text { on energy } \\
\text { resources }\end{array}$ & Reduction in expenditures by $4.8 \%$ & Reduction in expenditures by $4.2 \%$ & $\begin{array}{l}\text { Reduction in expenditures by } \\
\qquad 8.1 \%\end{array}$ \\
\hline $\begin{array}{l}\text { The expected } \\
\text { effect of the } \\
\text { program } \\
\text { implementation }\end{array}$ & $\begin{array}{l}\text { Improvement of energy resources using } \\
\text { efficiency in the course of manufacturing } \\
\text { activities leads to saving USD } 0.134 \\
\text { mln/year in terms of value. }\end{array}$ & $\begin{array}{l}\text { NPV for } 5 \text { years at a discount rate of } 20 \% \text { amounts to } \\
\text { USD } 0.155 \text { million. }\end{array}$ & $\begin{array}{l}\text { Enhancement of workforce } \\
\text { productivity up to } 15 \% \text { in } \\
\text { certain workshops. } \\
\text { Product quality improvement } \\
\text { due to reduction in number of } \\
\text { complaints by } 10 \% \text {. } \\
\text { Cost saving is USD } 0.233 \\
\text { mln/year, increasing the market } \\
\text { share by } 4 \% \text { by } 2021 .\end{array}$ \\
\hline
\end{tabular}

The third stage of the developed sequence of works assumes coordination of the formulated program with other development programs and the assessment of its impact on the achievement of the company's goals. The impact of the energy saving and energy efficiency improvement program was considered as an example of the practical implementation of the developed approach. The program was drafted with reference to implementation conditions of the third position option's activities. In order to determine the degree of changes of the main parameters of the company's previously adopted production program, two potential scenarios of the company's production volume change were investigated on expert judgment method (Figure 5). Under the first scenario, the history of changes in the company's output volume in the course of implementation of the developed program's activities was evaluated. As a result of these calculations, it was determined that under this scenario, the company will be able to increase its market share from $20 \%$ in 2018 to $28 \%$ by 2021 . The second scenario is based, first, on the negation of the possible impact of the developed program on changing the major parameters of the manufacturing program adopted earlier at the company and, second, it is based on the use of information about the existing trends in the company's output volume during the calculations. In this case, the company's market share will grow considerably leaner-from $20 \%$ in 2018 to $24 \%$ by 2021 . The acquired estimates do not contradict the results of the study [83], which concludes that the consideration of monetized multiple benefits can reduce the payback time of measures to increase energy efficiency by $40 \%-85 \%$. There is no contradiction to the results of the study [130], which substantiates the position that investments in energy efficiency improvement significantly affect the growth and competitiveness of medium and small enterprises. 


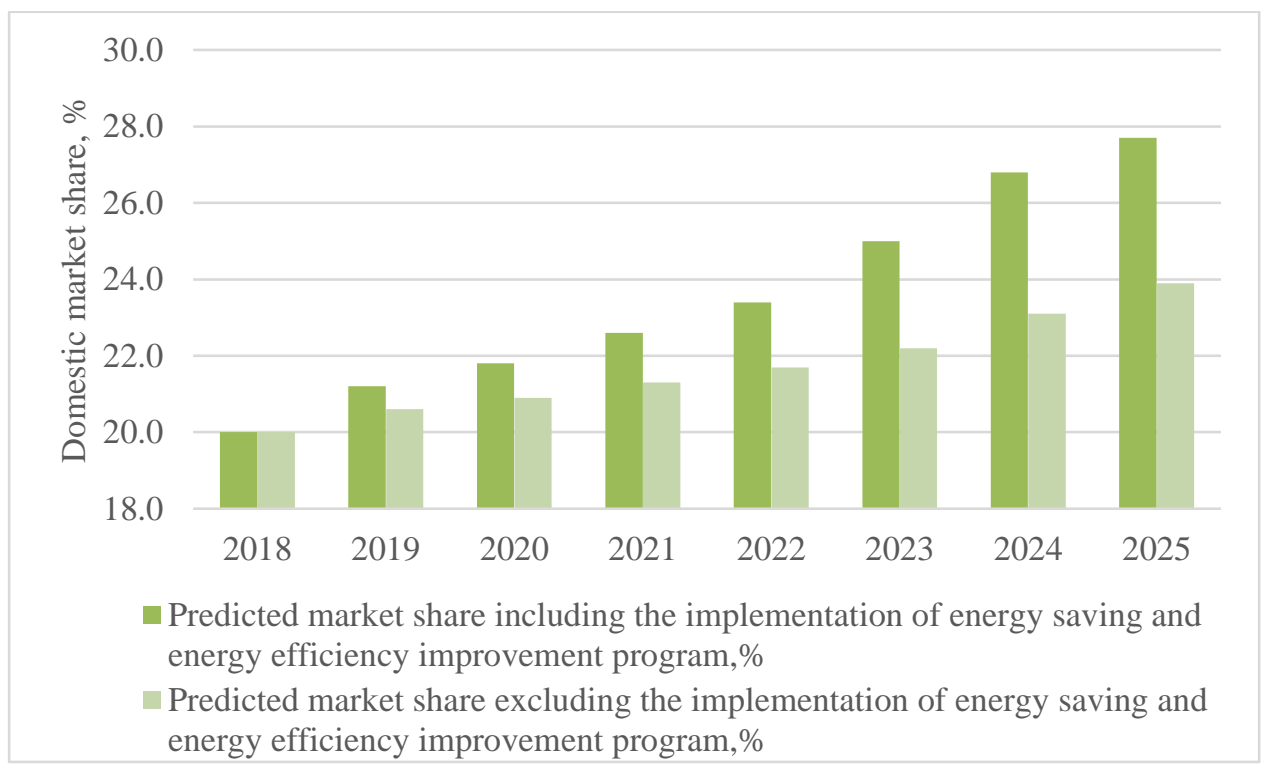

Figure 5. Predictive assessment of the impact of energy saving and energy efficiency improvement program on the potential change in the company's market share, \% (source: compiled by the authors).

The calculation results can be used further at the fourth stage of the developed sequence of works for the following purposes: first, to determine the need for resource allocation of the program and, second, to identify organizational conditions required for the implementation of the ready program. To coordinate the processes of energy saving and energy efficiency improvement management, on the one hand, and the processes of innovative development management, on the other hand, it is essential to pay special attention to the establishment of mutual compliance among them in the following areas. First, through the system of objectives and their decomposition among different departments of the company; second, through the distribution of tasks and functions among the relevant departments; third, through the delegation of responsibilities, rights and authorities within the organization; fourth, through the implemented information flow and the existing document flow. The represented areas of organizational changes within the company should be appropriately embodied in the system of company management and provide for the creation of favorable conditions for the strategic development of the company. All the above-mentioned is a prerequisite for bringing the developed approach to practical implementation at various industrial enterprises and companies performing miscellaneous activities.

It should be noted that our results do not contradict the results of empirical studies of other scientists in this field. Moreover, our study to assess the possible impact of energy efficiency on the results of the strategic development of a company develops theoretical studies on the problem of strategic multiple or non-energy benefits from energy efficiency in a company. A recently published literature review on multiple benefits in firm-level energy efficiency decisions includes fewer than 30 papers on the issue under study [84]. However, these works provide convincing evidence of the need to study the possible manifestations of various effects, including reducing production downtime, improving product quality, increasing productivity, etc. That is why in the conceptual approach we have implemented, firstly, the logic of identifying and analyzing non-energy benefits from improving energy efficiency, depending on its place in the system of managerial priorities of the enterprise's management, is substantiated. Secondly, the priorities of the company's management are determined to justify the choice of such areas of development for improving energy efficiency, which can be integrated into activities to achieve the operational, tactical and strategic goals of the company. Thirdly, a mathematical formulation of the problem under study is proposed to formalize decision-making algorithms at the company from the standpoint of increasing energy efficiency as a strategic priority for its development. It is quite obvious that the implementation of our approach, on the one hand, 
expands the analytical capabilities of analyzing energy efficiency processes in a company using the traditionally employed scheme of comparing the necessary costs with the expected effects. However, on the other hand, its use in solving applied problems of the development of economic entities sets strict requirements for the level of knowledge and the availability of relevant competencies among experts in the field of energy efficiency [88].

\section{Conclusions}

The study results allowed to confirm the proposed hypothesis that the existing mechanisms for energy saving and energy efficiency improvement management do not fully utilize the innovative potential of know-how in the field of energy technologies to achieve development targets. This situation is a major problem in the functioning of enterprises in various industries and areas of activity. To solve this problem, the concept of positioning the processes of energy saving and energy efficiency improvement in the company's management priorities system was proposed. The developed methodical approach was experimentally tested using the development and optimization of the program of the energy saving and energy efficiency improvement at the company as an example. The application of this approach has enabled providing the possibility of flexible adjustment of the program development process with reference to specific conditions of a certain company. All the above-mentioned enables unlocking the potential of energy saving and energy efficiency improvement in order to increase the growth of the company's performance efficiency.

Some constraints on the implementation of the suggested approach are imposed by the need for customizing the applied mathematical tools for each of the companies under study to achieve their goals. Its adaptation with regard to the conditions for business activities of small and medium-sized companies requires consideration of particular characteristics of their activities regarding both the management of energy saving and energy efficiency improvement and management of innovations.

The following activities might be carried out in the course of a further study. First, adaptation of the developed approach to address similar development problems at the regional and national levels of governing the national economies. Second, addressing the applied problems of managing energy saving and energy efficiency improvement at various levels of governing the national economies from the standpoint of their close integration with innovation management processes. Overall, the processes of energy saving and energy efficiency improvement might be considered as the key element of increasing the competitiveness of products in the context of the global economy's ongoing transition to the innovative way of development on the platform of the sixth technological wave.

Thus, the results obtained, first, expand scientific understanding of the impact of energy saving and energy efficiency improvement on the achievement of operational, tactical and strategic results of the company's activities in the context of the orientation of national economies towards the innovative way of development; second, they provide methodological decision support for the development of energy saving and energy efficiency programs, taking into account the management and organizational barriers; third, they are of practical interest in terms of addressing applied problems of the companies development representing various countries and economic sectors, primarily aimed at the increase in their competitiveness in the global economic space.

Author Contributions: Conceptualization, A.M.; methodology, A.M. and K.E.; writing—original draft, K.E.; writing-review and editing, A.M.; investigation, K.E. All authors have read and agreed to the published version of the manuscript.

Funding: The reported study was funded by RFBR, project number 20-310-70023.

Conflicts of Interest: The authors declare no conflict of interest.

\section{References}

1. Armeanu, D.Ş.; Vintilă, G.; Gherghina, Ş.C. Does renewable energy drive sustainable economic growth? Multivariate panel data evidence for EU-28 countries. Energies 2017, 10, 381. [CrossRef] 
2. Lehmann, P.; Creutzig, F.; Ehlers, M.H.; Friedrichsen, N.; Heuson, C.; Hirth, L.; Pietzcker, R. Carbon lock-out: Advancing renewable energy policy in Europe. Energies 2012, 5, 323-354. [CrossRef]

3. Li, Z.; Liao, G.; Wang, Z.; Huang, Z. Green loan and subsidy for promoting clean production innovation. J. Clean. Prod. 2018, 187, 421-431. [CrossRef]

4. Poulsen, R.T.; Johnson, H. The logic of business vs. the logic of energy management practice: Understanding the choices and effects of energy consumption monitoring systems in shipping companies. J. Clean. Prod. 2016, 112, 3785-3797. [CrossRef]

5. Kasperowicz, R.; Pinczyński, M.; Khabdullin, A. Modeling the power of renewable energy sources in the context of classical electricity system transformation. J. Int. Stud. 2017, 10, 264-272. [CrossRef]

6. Simionescu, M.; Bilan, Y.; Krajňáková, E.; Streimikiene, D.; Gędek, S. Renewable energy in the electricity sector and GDP per capita in the European Union. Energies 2019, 12, 2520. [CrossRef]

7. Shindina, T.; Streimikis, J.; Sukhareva, Y.; Nawrot, Ł. Social and economic properties of the energy markets. Econ. Sociol. 2018, 11, 334-344. [CrossRef]

8. Finnerty, N.; Sterling, R.; Coakley, D.; Contreras, S.; Coffey, R.; Keane, M.M. Development of a Global Energy Management System for non-energy intensive multi-site industrial organisations: A methodology. Energy 2017, 136, 16-31. [CrossRef]

9. Tvaronavičienè, M.; Prakapienè, D.; Garškaitè-Milvydienė, K.; Prakapas, R.; Nawrot, Ł. Energy efficiency in the long run in the selected European countries. Econ. Sociol. 2018, 11, 245-254. [CrossRef]

10. Stavytskyy, A.; Kharlamova, G.; Giedraitis, V.; Šumskis, V. Estimating the interrelation between energy security and macroeconomic factors in European countries. J. Int. Stud. 2018, 11, 217-238. [CrossRef]

11. Painuly, J.P.; Park, H.; Lee, M.K.; Noh, J. Promoting energy efficiency financing and ESCOs in developing countries: Mechanisms and barriers. J. Clean. Prod. 2003, 11, 659-665. [CrossRef]

12. De Castro Camioto, F.; Moralles, H.F.; Mariano, E.B.; do Nascimento Rebelatto, D.A. Energy efficiency analysis of G7 and BRICS considering total-factor structure. J. Clean. Prod. 2016, 122, 67-77. [CrossRef]

13. Chai, K.H.; Yeo, C. Overcoming energy efficiency barriers through systems approach-A conceptual framework. Energy Policy 2012, 46, 460-472. [CrossRef]

14. Costa-Campi, M.T.; García-Quevedo, J.; Segarra, A. Energy efficiency determinants: An empirical analysis of Spanish innovative firms. Energy Policy 2015, 83, 229-239. [CrossRef]

15. Thollander, P.; Palm, J. Industrial energy management decision making for improved energy efficiency—Strategic system perspectives and situated action in combination. Energies 2015, 8, 5694-5703. [CrossRef]

16. Zhu, L.; Chen, J. A dynamic approach to energy efficiency estimation in the large-scale chemical plant. J. Clean. Prod. 2019, 212, 1072-1085. [CrossRef]

17. Lacerda, J.S.; Van den Bergh, J.C. International diffusion of renewable energy innovations: Lessons from the lead markets for wind power in China, Germany and USA. Energies 2014, 7, 8236-8263. [CrossRef]

18. Brockway, P.E.; Saunders, H.; Heun, M.K.; Foxon, T.J.; Steinberger, J.K.; Barrett, J.R.; Sorrell, S. Energy rebound as a potential threat to a low-carbon future: Findings from a new exergy-based national-level rebound approach. Energies 2017, 10, 51. [CrossRef]

19. Patterson, M.G. What is energy efficiency? Concepts, indicators and methodological issues. Energy Policy 1996, 24, 377-390. [CrossRef]

20. Bobylev, S.N.; Kudryavtseva, O.V.; Yakovleva, Y.Y. Regional priorities of green economy. Econ. Reg. 2015, 2,42 .

21. Costantini, V.; Crespi, F.; Palma, A. Characterizing the policy mix and its impact on eco-innovation: A patent analysis of energy-efficient technologies. Res. Policy 2017, 46, 799-819. [CrossRef]

22. Barreto, L.; Kemp, R. Inclusion of technology diffusion in energy-systems models: Some gaps and needs. J. Clean. Prod. 2008, 16, S95-S101. [CrossRef]

23. Valderrama, C.; Granados, R.; Cortina, J.L.; Gasol, C.M.; Guillem, M.; Josa, A. Implementation of best available techniques in cement manufacturing: A life-cycle assessment study. J. Clean. Prod. 2012, 25, 60-67. [CrossRef]

24. Saygin, D.; Worrell, E.; Patel, M.K.; Gielen, D.J. Benchmarking the energy use of energy-intensive industries in industrialized and in developing countries. Energy 2011, 36, 6661-6673. [CrossRef]

25. Jaffe, A.B.; Stavins, R.N. The energy-efficiency gap What does it mean? Energy Policy 1994, 22, 804-810. [CrossRef] 
26. Dudin, M.N.; Frolova, E.E.; Protopopova, O.V.; Andrey Alievich Mamedov, A.A.; Odintsov, S.V. Study of innovative technologies in the energy industry: Nontraditional and renewable energy sources. Entrep. Sustain. Issues 2019, 6, 1704-1713. [CrossRef]

27. El Iysaouy, L.; El Idrissi, N.E.; Tvaronavičienė, M.; Lahbabi, M.; Oumnad, A. Towards energy efficiency: Case of Morocco. Insights Reg. Dev. 2019, 1, 259-271. [CrossRef]

28. Rezk, M.R.; Radwan, A.; Salem, N.M.; Sakr, T.M.; Tvaronavičienè, M. Foresight for sustainable energy policy in Egypt: Results from a Delphi survey. Insights Reg. Dev. 2019, 1, 357-369. [CrossRef]

29. Popp, D. Induced innovation and energy prices. Am. Econ. Rev. 2002, 92, 160-180. [CrossRef]

30. Allcott, H.; Greenstone, M. Is there an energy efficiency gap? J. Econ. Perspect. 2012, 26, 3-28. [CrossRef]

31. Lee, K.H. Drivers and barriers to energy efficiency management for sustainable development. Sustain. Dev. 2015, 23, 16-25. [CrossRef]

32. Schulze, M.; Nehler, H.; Ottosson, M.; Thollander, P. Energy management in industry-A systematic review of previous findings and an integrative conceptual framework. J. Clean. Prod. 2016, 112, 3692-3708. [CrossRef]

33. Garrone, P.; Grilli, L.; Mrkajic, B. The energy-efficient transformation of EU business enterprises: Adapting policies to contextual factors. Energy Policy 2017, 109, 49-58. [CrossRef]

34. Lanzi, E. Impacts of innovation: Lessons from the empirical evidence. In Encyclopedia of Energy, Natural Resource, and Environmental Economics; Shogren, J.F., Ed.; Elsevier: Amsterdam, The Netherlands, 2013; pp. 82-88.

35. Fri, R.W.; Savitz, M.L. Rethinking energy innovation and social science. Energy Res. Soc. Sci. 2014, 1, $183-187$. [CrossRef]

36. Clark, W.W. Agile Energy Systems: Global Distributed On-Site and Central Grid Power; Elsevier: Amsterdam, The Netherlands, 2017.

37. Newell, R.G.; Jaffe, A.B.; Stavins, R.N. The induced innovation hypothesis and energy-saving technological change. Q. J. Econ. 1999, 114, 941-975. [CrossRef]

38. Urpelainen, J. Export orientation and domestic electricity generation: Effects on energy efficiency innovation in select sectors. Energy Policy 2011, 39, 5638-5646. [CrossRef]

39. Berardi, U. A cross-country comparison of the building energy consumptions and their trends. RCR 2017, 123, 230-241. [CrossRef]

40. Vlasov, A.I.; Shakhnov, V.A.; Filin, S.S.; Krivoshein, A.I. Sustainable energy systems in the digital economy: Concept of smart machines. Entrep. Sustain. Issues 2019, 6, 1975-1986. [CrossRef]

41. Gerstlberger, W.; Knudsen, M.P.; Dachs, B.; Schröter, M. Closing the energy-efficiency technology gap in European firms? Innovation and adoption of energy efficiency technologies. J. Eng. Technol. Manag. 2016, 40, 87-100. [CrossRef]

42. Kim, Y.J.; Brown, M. Impact of domestic energy-efficiency policies on foreign innovation: The case of lighting technologies. Energy Policy 2019, 128, 539-552. [CrossRef]

43. Cagno, E.; Ramirez-Portilla, A.; Trianni, A. Linking energy efficiency and innovation practices: Empirical evidence from the foundry sector. Energy Policy 2015, 83, 240-256. [CrossRef]

44. Rizzi, F.; Annunziata, E.; Frey, M. The relationship between organizational culture and energy performance: A municipal energy manager level study. Bus. Strategy Environ. 2018, 27, 694-711. [CrossRef]

45. Yuan, R.; Zhao, T. Changes in CO2 emissions from China's energy-intensive industries: A subsystem input-output decomposition analysis. J. Clean. Prod. 2016, 117, 98-109. [CrossRef]

46. Miao, C.; Fang, D.; Sun, L.; Luo, Q.; Yu, Q. Driving effect of technology innovation on energy utilization efficiency in strategic emerging industries. J. Clean. Prod. 2018, 170, 1177-1184. [CrossRef]

47. Song, C.; Oh, W. Determinants of innovation in energy intensive industry and implications for energy policy. Energy Policy 2015, 81, 122-130. [CrossRef]

48. Marchand, H.; Martin, A.; Weismantel, R.; Wolsey, L. Cutting planes in integer and mixed integer programming. Discret. Appl. Math. 2002, 123, 397-446. [CrossRef]

49. Solnørdal, M.T.; Foss, L. Closing the energy efficiency gap-A systematic review of empirical articles on drivers to energy efficiency in manufacturing firms. Energies 2018, 11, 518. [CrossRef]

50. Gerstlberger, W.; Præst Knudsen, M.; Stampe, I. Sustainable development strategies for product innovation and energy efficiency. Bus. Strategy Environ. 2014, 23, 131-144. [CrossRef]

51. Doran, J.; Ryan, G. The importance of the diverse drivers and types of environmental innovation for firm performance. Bus. Strategy Environ. 2016, 25, 102-119. [CrossRef] 
52. Melnik, A.N.; Ermolaev, K.A. Top management course from the perspective of its impact on the activation of energy-saving activities in the enterprise. In International Multidisciplinary Scientific Conferences on Social Sciences and Arts; SGEM: Albena, Bulgaria, 2014; pp. 725-732.

53. Melnik, A.N.; Ermolaev, K.A. An optimization approach to program development for energy saving and energy efficiency enhancement at enterprises. Econ. Anal. Theory Pract. 2019, 18, 200-216. [CrossRef]

54. Zhou, L.; Li, J.; Li, F.; Meng, Q.; Li, J.; Xu, X. Energy consumption model and energy efficiency of machine tools: A comprehensive literature review. J. Clean. Prod. 2016, 112, 3721-3734. [CrossRef]

55. Afshari, A.; Friedrich, L.A. Inverse modeling of the urban energy system using hourly electricity demand and weather measurements, Part 1: Black-box model. Energy Build. 2017, 157, 126-138. [CrossRef]

56. Xiong, S.; Ma, X.; Ji, J. The impact of industrial structure efficiency on provincial industrial energy efficiency in China. J. Clean. Prod. 2019, 215, 952-962. [CrossRef]

57. Yao, Z.M.; Qian, Z.Q.; Li, R.; Hu, E. Energy efficiency analysis of marine high-powered medium-speed diesel engine base on energy balance and exergy. Energy 2019, 176, 991-1006. [CrossRef]

58. Giacone, E.; Mancò, S. Energy efficiency measurement in industrial processes. Energy 2012, 38, 331-345. [CrossRef]

59. Olanrewaju, O.A.; Jimoh, A.A. Review of energy models to the development of an efficient industrial energy model. Renew. Sustain. Energy Rev. 2014, 30, 661-671. [CrossRef]

60. Zhang, L.; Long, R.; Chen, H.; Huang, X. Performance changes analysis of industrial enterprises under energy constraints. RCR 2018, 136, 248-256. [CrossRef]

61. Ma, S.; Zhang, Y.; Lv, J.; Yang, H.; Wu, J. Energy-cyber-physical system enabled management for energy-intensive manufacturing industries. J. Clean. Prod. 2019, 226, 892-903. [CrossRef]

62. Tari, M.H.; Söderström, M. Modelling of thermal energy storage in industrial energy systems the method development of MIND. Appl. Therm. Eng. 2002, 22, 1195-1205. [CrossRef]

63. Gong, M. Optimization of industrial energy systems by incorporating feedback loops into the MIND method. Energy 2003, 28, 1655-1669. [CrossRef]

64. Karlsson, M. The MIND method: A decision support for optimization of industrial energy systems-principles and case studies. Appl. Energy 2011, 88, 577-589. [CrossRef]

65. Thollander, P.; Mardan, N.; Karlsson, M. Optimization as investment decision support in a Swedish medium-sized iron foundry-a move beyond traditional energy auditing. Appl. Energy 2009, 86, 433-440. [CrossRef]

66. Karlsson, M.; Wolf, A. Using an optimization model to evaluate the economic benefits of industrial symbiosis in the forest industry. J. Clean. Prod. 2008, 16, 1536-1544. [CrossRef]

67. Malatji, E.M.; Zhang, J.; Xia, X. A multiple objective optimisation model for building energy efficiency investment decision. Energy Build. 2013, 61, 81-87. [CrossRef]

68. Diakaki, C.; Grigoroudis, E.; Kabelis, N.; Kolokotsa, D.; Kalaitzakis, K.; Stavrakakis, G. A multi-objective decision model for the improvement of energy efficiency in buildings. Energy 2010, 35, 5483-5496. [CrossRef]

69. Soetanto, R.; Zhang, S.; Pan, W.; Kumaraswamy, M. A multi-criteria decision framework for the selection of low carbon building measures for office buildings in Hong Kong. Int. J. Energy Sect. Manag. 2014, 8, $456-476$.

70. Trianni, A.; Cagno, E.; Neri, A.; Howard, M. Measuring industrial sustainability performance: Empirical evidence from Italian and German manufacturing small and medium enterprises. J. Clean. Prod. 2019, 229, 1355-1376. [CrossRef]

71. Biel, K.; Glock, C.H. Systematic literature review of decision support models for energy-efficient production planning. Comput. Ind. Eng. 2016, 101, 243-259. [CrossRef]

72. Cooremans, C. Make it strategic! Financial investment logic is not enough. Energy Effic. 2011, 4, 473-492. [CrossRef]

73. Cooremans, C.; Schönenberger, A. Energy management: A key driver of energy-efficiency investment? J. Clean. Prod. 2019, 230, 264-275. [CrossRef]

74. Cooremans, C. Investment in energy efficiency: Do the characteristics of investments matter? Energy Effic. 2012, 5, 497-518. [CrossRef]

75. Fresner, J.; Krenn, C.; Kleshchov, A.; Tomasi, F. Exploratory research into energy efficiency investment and strategy. Tekhnol. Audit Rez. Proiz. 2019, 2, 16-27. [CrossRef]

76. Rasmussen, J. The additional benefits of energy efficiency investments-A systematic literature review and a framework for categorisation. Energy Effic. 2017, 10, 1401-1418. [CrossRef] 
77. Nehler, T. A systematic literature review of methods for improved utilisation of the non-energy benefits of industrial energy efficiency. Energies 2018, 11, 3241. [CrossRef]

78. Cagno, E.; Moschetta, D.; Trianni, A. Only non-energy benefits from the adoption of energy efficiency measures? A novel framework. J. Clean. Prod. 2019, 212, 1319-1333. [CrossRef]

79. Cagno, E.; Worrell, E.; Trianni, A.; Pugliese, G. A novel approach for barriers to industrial energy efficiency. Renew. Sustain. Energy Rev. 2013, 19, 290-308. [CrossRef]

80. Trianni, A.; Cagno, E.; Farné, S. Barriers, drivers and decision-making process for industrial energy efficiency: A broad study among manufacturing small and medium-sized enterprises. Appl. Energy 2016, 162, 1537-1551. [CrossRef]

81. Fawcett, T.; Killip, G. Re-thinking energy efficiency in European policy: Practitioners' use of 'multiple benefits' arguments. J. Clean. Prod. 2019, 210, 1171-1179. [CrossRef]

82. Trianni, A.; Cagno, E.; Marchesani, F.; Spallina, G. Classification of drivers for industrial energy efficiency and their effect on the barriers affecting the investment decision-making process. Energy Effic. 2017, 10, 199-215. [CrossRef]

83. Wagner, C.; Obermeyer, M.; Lüchinger, R. A methodology for the assessment of multiple benefits of industrial energy efficiency measures. SN Appl. Sci. 2020, 2, 270. [CrossRef]

84. Killip, G.; Fawcett, T.; Cooremans, C.; Wijns-Craus, W.; Subramani, K.; Voswinkel, F. Multiple Benefits of Energy Efficiency at the Firm Level: A Literature Review; European Council for an Energy Efficient Economy: Stockholm, Sweden, 2019.

85. Saygin, D.; Patel, M.K.; Worrell, E.; Gielen, D. Global Benchmarking for the Industrial Sector: Application and Analysis of Competitiveness; United Nations Industrial Development Organization: New York, NY, USA, 2010.

86. UNIDO. Industrial Energy Efficiency for Sustainable Wealth Creation: Capturing Environmental, Economic and Social Dividends. Industrial Development Report. 2011. Available online: https://www.unido.org/sites/ default/files/2012-01/UNIDO_FULL_REPORT_EBOOK_0.pdf (accessed on 22 January 2020).

87. International Energy Outlook 2018 (IEO2018); US Energy Information Administration (EIA): Washington, DC, USA, 2018. Available online: https://www.iea.org/reports/world-energy-outlook-2018 (accessed on 22 January 2020).

88. Palm, J.; Thollander, P. Reframing energy efficiency in industry: A discussion of definitions, rationales, and management practices. In Energy and Behaviour; Academic Press: New York, NY, USA, 2020; pp. 153-175.

89. Cagno, E.; Trianni, A. Evaluating the barriers to specific industrial energy efficiency measures: An exploratory study in small and medium-sized enterprises. J. Clean. Prod. 2014, 82, 70-83. [CrossRef]

90. Cagno, E.; Trianni, A.; Spallina, G.; Marchesani, F. Drivers for energy efficiency and their effect on barriers: Empirical evidence from Italian manufacturing enterprises. Energy Effic. 2017, 10, 855-869. [CrossRef]

91. Sola, A.V.; Mota, C.M. Influencing factors on energy management in industries. J. Clean. Prod. 2020, 248, 119263. [CrossRef]

92. Melnik, A.N.; Ermolaev, K.A. Conceptual framework for managing the energy saving and energy efficiency at industrial enterprises in the context of their innovative development. Econ. Anal. Theory Pract. 2019, 18, 22-39. [CrossRef]

93. Poveda-Orjuela, P.P.; García-Díaz, J.C.; Pulido-Rojano, A.; Cañón-Zabala, G. ISO 50001: 2018 and its application in a comprehensive management system with an energy-performance focus. Energies 2019, 12, 4700. [CrossRef]

94. Weinert, N.; Chiotellis, S.; Seliger, G. Methodology for planning and operating energy-efficient production systems. CIRP Ann. 2011, 60, 41-44. [CrossRef]

95. Springer, C. Assessing energy intensity and retrofit opportunities for the aluminum industry: Lessons from Vietnam. RCR 2018, 131, 235-246. [CrossRef]

96. Wei, T.; Zhou, J.; Zhang, H. Rebound effect of energy intensity reduction on energy consumption. RCR 2019, 144, 233-239. [CrossRef]

97. Bunse, K.; Vodicka, M.; Schönsleben, P.; Brülhart, M.; Ernst, F.O. Integrating energy efficiency performance in production management-gap analysis between industrial needs and scientific literature. J. Clean. Prod. 2011, 19, 667-679. [CrossRef]

98. Kim, J.J. Economic analysis on energy saving technologies for complex manufacturing building. RCR 2017, 123, 249-254. [CrossRef] 
99. Johansson, I.; Mardan, N.; Cornelis, E.; Kimura, O.; Thollander, P. Designing policies and programmes for improved energy efficiency in industrial SMEs. Energies 2019, 12, 1338. [CrossRef]

100. Sokka, L.; Pakarinen, S.; Melanen, M. Industrial symbiosis contributing to more sustainable energy use-An example from the forest industry in Kymenlaakso, Finland. J. Clean. Prod. 2011, 19, 285-293. [CrossRef]

101. Wang, Y.; Li, H.; Song, Q.; Qi, Y. The consequence of energy policies in China: A case study of the iron and steel sector. RCR 2017, 117, 66-73. [CrossRef]

102. Zhu, Q.; Cote, R.P. Integrating green supply chain management into an embryonic eco-industrial development: A case study of the Guitang Group. J. Clean. Prod. 2004, 12, 1025-1035. [CrossRef]

103. Gielen, D.; Taylor, M. Modelling industrial energy use: The IEAs energy technology perspectives. Energy Econ. 2007, 29, 889-912. [CrossRef]

104. Janda, K.B.; Patrick, J.; Granell, R.; Bright, S.; Wallom, D.; Layberry, R. A WICKED approach to retail sector energy management. In Proceedings of the ECEEE Summer Study, Hyères, France, 1-6 June 2015; pp. 1-6.

105. Herrmann, C.; Thiede, S. Process chain simulation to foster energy efficiency in manufacturing. CIRP J. Manuf. Sci. Technol. 2009, 4, 221-229. [CrossRef]

106. Fleiter, T.; Hirzel, S.; Worrell, E. The characteristics of energy-efficiency measures-A neglected dimension. Energy Policy 2012, 51, 502-513. [CrossRef]

107. Dunant, C.F.; Skelton, A.C.; Drewniok, M.P.; Cullen, J.M.; Allwood, J.M. A marginal abatement cost curve for material efficiency accounting for uncertainty. RCR 2019, 144, 39-47. [CrossRef]

108. Lopes, J.R.N.; de Araújo Kalid, R.; Rodríguez, J.L.M.; Ávila Filho, S. A new model for assessing industrial worker behavior regarding energy saving considering the theory of planned behavior, norm activation model and human reliability. RCR 2019, 145, 268-278. [CrossRef]

109. Pye, M.; McKane, A. Making a stronger case for industrial energy efficiency by quantifying non-energy benefits. RCR 2000, 28, 171-183. [CrossRef]

110. Zhang, Y.; Ma, S.; Yang, H.; Lv, J.; Liu, Y. A big data driven analytical framework for energy-intensive manufacturing industries. J. Clean. Prod. 2018, 197, 57-72. [CrossRef]

111. Henriques, J.; Catarino, J. Motivating towards energy efficiency in small and medium enterprises. J. Clean. Prod. 2016, 139, 42-50. [CrossRef]

112. Gliedt, T.; Hoicka, C.E. Energy upgrades as financial or strategic investment? Energy Star property owners and managers improving building energy performance. Appl. Energy 2015, 147, 430-443. [CrossRef]

113. Rotzek, J.N.; Scope, C.; Günther, E. What energy management practice can learn from research on energy culture? Sustain. Account. Manag. Policy J. 2018. [CrossRef]

114. Cooremans, C. Energy-efficiency investments and energy management: An interpretative perspective. In Proceedings of the International Conference on Energy Efficiency in Commercial Buildings, IEECB'12, Frankfurt, Germany, 18-19 April 2012; Available online: https://www.researchgate.net/profile/Catherine_ Cooremans/publication/267764698_Energy-efficiency_investments_and_energy_management_An_ interpretative_perspective/links/545a2d740cf2cf51648438bf.pdf (accessed on 22 January 2020).

115. Laurikka, H.; Koljonen, T. Emissions trading and investment decisions in the power sector-a case study in Finland. Energy Policy 2006, 34, 1063-1074. [CrossRef]

116. Cai, Y.P.; Huang, G.H.; Yang, Z.F.; Tan, Q. Identification of optimal strategies for energy management systems planning under multiple uncertainties. Appl. Energy 2009, 86, 480-495. [CrossRef]

117. Assefa, B.G.; Özkasap, Ö. A survey of energy efficiency in SDN: Software-based methods and optimization models. J. Netw. Comput. Appl. 2019, 137, 127-143. [CrossRef]

118. Melnik, A.; Ermolaevb, K. Study on the processes of energy conservation and efficient energy use in the innovative development programs of Russian companies. J. Eng. Appl. Sci. 2018, 13, 14-18.

119. Melnik, A.N.; Lukishina, L.V.; Sadriev, A.R. Formation of the system of indicators to assess the impact of energy efficiency on the innovative development of the enterprise. Int. J. Appl. Eng. Res. 2015, 10, 40991-40997.

120. Fernando, Y.; Hor, W.L. Impacts of energy management practices on energy efficiency and carbon emissions reduction: A survey of Malaysian manufacturing firms. RCR 2017, 126, 62-73. [CrossRef]

121. Bull, R.; Janda, K.B. Beyond feedback: Introducing the 'engagement gap' in organizational energy management. Build. Res. Inf. 2018, 46, 300-315. [CrossRef]

122. Melnik, A.N.; Ermolaev, K.A.; Kuzmin, M.S. Mechanism for adjustment of the companies innovative activity control indicators to their strategic development goals. GJFSM 2019, 20, 189-218. [CrossRef] 
123. Sadriev, A.R. Problems and prospects of networking mechanism using in energy systems innovation development. MEJSR 2013, 17, 1453-1456.

124. Kim, K.; Kim, Y. International comparison of industrial $\mathrm{CO}_{2}$ emission trends and the energy efficiency paradox utilizing production-based decomposition. Energy Econ. 2012, 34, 1724-1741. [CrossRef]

125. Zhou, P.; Ang, B.W.; Zhou, D.Q. Measuring economy-wide energy efficiency performance: A parametric frontier approach. Appl. Energy 2012, 90, 196-200. [CrossRef]

126. Garrone, P.; Grilli, L.; Mrkajic, B. The role of institutional pressures in the introduction of energy-efficiency innovations. Bus. Strategy Environ. 2018, 27, 1245-1257. [CrossRef]

127. Amador, J. Energy content in manufacturing exports: A cross-country analysis. Energy Econ. 2012, 34, 1074-1081. [CrossRef]

128. Murty, K.G. Linear Programming; Macmillan: Chichester, UK, 1983.

129. Land, A.H.; Doig, A.G. An automatic method for solving discrete programming problems. In 50 Years of Integer Programming 1958-2008; Springer: Berlin/Heidelberg, Germany, 2010; pp. 105-132.

130. Özbuğday, F.C.; Fındık, D.; Özcan, K.M.; Başçı, S. Resource efficiency investments and firm performance: Evidence from European SMEs. J. Clean. Prod. 2020, 252, 119824. [CrossRef]

(C) 2020 by the authors. Licensee MDPI, Basel, Switzerland. This article is an open access article distributed under the terms and conditions of the Creative Commons Attribution (CC BY) license (http://creativecommons.org/licenses/by/4.0/). 